\title{
Banaz’da İki Son Neolitik/İlk Kalkolitik Çağ Yerleşimi: Ada Höyük ve Mercimeklik
}

\section{Two Late Neolithic/Early Chalcolithic Age Settlements in Banaz: Ada Mound And Mercimeklik}

\section{Harun OY*}

\author{
Ordu Üniversitesi Fen Edebiyat Fakültesi, Tarih Bölümü, harun oy@hotmail.com
}

ORCID Numarası I ORCID Number : 0000-0002-1901-5128

ÖZ

\begin{abstract}
Banaz, Uşak ilinin doğusunda Afyonkarahisar ve Kütahya ile sınır olan ilçedir. Banaz'da gerçekleştirdiğimiz yüzey araştırmaları sonucunda bölgede çok sayıda İTÇ yerleşimi tespit edilmiştir. Ada Höyük ve Mercimeklik yerleşmeleri Banaz ilçesinde Sürmecik Orta Paeolitik yerleşmesinden sonra en erken döneme tarihlenen iki yerleşimdir. Ada Höyük Son Neolitik/İlk Kalkolitik Çağ, Mercimeklik ise İlk Kalkolitik Çağ buluntuları vermektedir. Uşak ilinde Neolitik ve Kalkolitik Çağ yerleşmeleri azdır. Bu nedenle Banaz'daki bu iki yerleşim bölge araştırmaları için önemlidir. Bu makalede Ada aHöyük ve Mercimeklik yerleşmesinden toplanan 49 adet Neolitik ve Kalkolitik Çağ çanak çömleği değerlendirilmektedir. Neolitik Çağ çanak çömleği (40 adet) kahverengi, kırmızı ve gri astarlı mallardan oluşmaktadır. Açık ve kapalı formlar vardır. Ayrıca minyatür kaplarda bulunur. Dikey kulp, sepet kulp ve ip delikli tutamaklar belirgindir. Dipler düzdür. Neolitik Çağ kapları genellikle bezemesiz olmakla beraber bezemeli olanlar da vardır. Konsantrik daire bezemeli örnek dikkat çekicidir. Kalkolitik Çağ çanak çömleği (9 adet) boya bezemelidir. Kahverengi, beyaz, pembe ve mor astarlı mal grupları belirlenmiştir. Son Neolitik Çağ kaplarının Göller Yöresi, Batı Anadolu kıyıları ve kuzeydeki Kütahya bölgesi ile ilişkili olduğu belirlenmiştir. Orta Anadolu ile ilişkiler ise daha azdır. İlk Kalkolitik Çağ kapları Göller Yöresi ile olan güçlü ilişkileri vurgulamaktadır. Yine Afyonkarahisar ile olan ilişkiler vardır. Morumsu kırmızı astarlı örneklerin varlığı kuzeydeki Aslanapa kültürünün Uşak ilindeki yayılımını göstermesi bakımından önemlidir.
\end{abstract}

Anahtar Kelimeler: Son Neolitik, İlk Kalkolitik, Uşak, Keramik, İçbatı Anadolu.

\begin{abstract}
Banaz is a district of Afyonkarahisar and Kütahya in the east of Uşak province. As a result of the surveys we conducted in Banaz, several EBA settlements were identified. Ada Mound and Mercimeklik settlements are the two settlements dating to the earliest period after the Sürmecik Middle Paleolithic settlement in Banaz. The Late Neolithic/Early Chalcolithic Age finds at Ada Mound and Early Chalcolithic Age finds at Mercimeklik were identified. The Neolithic and Chalcolithic Age settlements in Uşak are few. Therefore, these two settlements in Banaz are important for regional surveys. In this article, 49 Neolithic and Chalcolithic Age sherds collected from Ada Mound and Mercimeklik settlements are evaluated. Neolithic pottery (40 pieces) consists of brown, red and gray ware. There are open and closed forms. There are also miniature vessels. The vertical handle, basket handle and pierced lug are evident. Bottoms are flat. Neolithic sherds are generally not decorated. The example with concentric circle decoration is noteworthy. Chalcolithic Age sherds ( 9 pieces) are decorated with paint. Brown, white, pink and purple groups were determined. It was determined that the Late Neolithic sherds were related to the Lakes Region, West Anatolian coast and Kütahya region in the north. Relations with Central Anatolia are less. The Early Chalcolithic Age sherds emphasize the strong relations with the Lakes Region. Again, there are relations with Afyonkarahisar. The presence of purplish red samples is important because it shows the spread of Aslanapa culture in Uşak province.
\end{abstract}

Key Words: Late Neolithic, Early Chalcolithic, Uşak, Ceramic, Inland Western Anatolia. 


\section{Giriş}

Banaz, İçbatı Anadolu'da Uşak ilinin doğusunda Afyonkarahisar'la sınır olan ilçesidir (Harita 1). İlçenin kuzeyinde Kütahya, batısında Uşak merkez, güneyinde Sivaslı ilçesi, doğusunda Afyonkarahisar ilinin Hocalar ve Sinanpaşa ilçeleri yer alır. Banaz'ın, denizden yüksekliği 914 metre ve yüzölçümü 1032 km2'dir. Banaz ilçesi 669 km2'lik orman alanıyla il genelinde en fazla ormanlık alana sahiptir. Banaz, yükseltisi 900-1000 m arasında değişen dalgalı düzlüklerden meydana gelmiştir. İlçenin kuzeyinde Murat Dağı, doğusunda Ahır Dağı ve güneydoğusunda Bulkaz Dağı bulunmaktadır (Yalçınlar, 1955, s. 58-60). 2312 m yüksekliğindeki Murat Dağı, Kütahya’nın Gediz ilçesi ile Banaz arasında sınır oluşturmakta olup 1200-1800 metreye varan birçok tepe ve yaylaları Banaz ilçesi sınırları içinde yer alır. Banaz ilçesi ve Murat Dağı çevresi, geniş ormanları, su kaynakları, zengin jeotermal kaynakları ve madenleri ile de önemli bir bölgedir.

İlçenin kuzeyindeki Murat Dağından kaynağını alan Banaz Çayı güneydeki Banaz Ovasını sulayarak Büyük Menderes nehrine ulaşmaktadır ve Büyük Menderes'in en önemli kollarından birisidir. Banaz Çayı haricinde ilçede çok sayıda küçük akarsu ve dere bulunmakta olup bölgeyi beslemektedir. İlçenin güneyinde 6500 hektarlık Banaz Ovası bulunur ve bu ova kuzeydoğudan güneybatıya uzanır.

Ankara-İzmir karayolu Banaz'ın merkezinden geçtiği için ilçe ulaşım açısından önemli bir konumdadır. İlçe günümüzde olduğu kadar prehistorik dönemlerde de ulaşım açısından önemli bir bölge olmuştur. Banaz Ovası ve Murat Dağı çevresinden önemli yollar geçmektedir. Banaz Ovası, Ayvacık Köyü ve Yazıtepe Köyü üzerinden Hocalar, Sandıklı Ovası ve Afyonkarahisar'a yol bağlantısı bulunmaktadır. Bu güzergah bu bölgede erken dönemlerden itibaren özellikle İlk Tunç Çağı ve Orta Tunç Çağında kullanılmış olan doğal yol bağlantısıdır. Bu güzergah Susuz Höyük, Ayvacık Höyük, Yazıtepe-Erenler Höyük üzerinden Hocalar, Sandıklı ve Afyonkarahisar'a bağlanmaktadır. Sandıklı üzerinden güneye doğru Burdur-Isparta ve Göller Yöresine bağlantı vardır. Banaz Ovası ile kuzeyde bulunan Murat Dağının etrafı dolaşılarak Kütahya, Aslanapa ve Altıntaş bölgeleri ile bağlantı kurulmaktadır.

Banaz'ın bulunduğu bölge İçbatı Anadolu'da yer almaktadır. Banaz'a sınır olan Afyonkarahisar'da Son Neolitik ve İlk Kalkolitik Çağ yerleşmeleri yapılan araştırmalarla ortaya konulmuştur. Banaz'ın kuzeyindeki Kütahya ve çevresinde Fındık Kayabaşı, Akmakça yerleşmeleri mevcuttur. Güneydeki Denizli'de de erken dönem yerleşmeleri bilinmektedir. Uşak ilinin komşu olduğu bu illerde Neolitik ve Kalkolitik yerleşmeler bilinmesine karşın Uşak ilinin Neolitik ve Kalkolitik dönemleri hakkında fazla bir bilgi bulunmamaktadır. Bu nedenle Banaz çevresindeki bu iki yerleşme yeri bölgenin erken dönem yerleşimler bakımından önem arz etmektedir.

Banaz çevresinin yerleşime uygun coğrafyası sebebiyle Orta Paleolitik Çağdan itibaren bölgede yerleşimin var olduğu tespit edilmiştir. Bizim yaptığımız araştırmalarda ise Ada Höyük yerleşimi Neolitik ve Kalkolitik Çağa kadar uzanmaktadır. Mercimeklik/Mercimekli Tepe ise İlk Kalkolitik 
Çağda iskan edilmiştir. Az sayıdaki bu yerleşmeler sadece Uşak için değil bölgenin erken dönemlerinin araştırılması açısından da önemlidir. İTÇ’de bölgede yerleşme sayısında büyük bir artış söz konusudur.

Batı Anadolu'nun genelinde Neolitik ve Kalkolitik Çağ yerleşmeleri bilinmektedir. Uşak'ta ve Banaz'da ise Orta Paleolitik döneme ait buluntuların tespiti burasını ön plana çıarmaktadır. Bölgenin erken dönemleri için ve yerleşim devamlılığını göstermesi bakımından Ada Höyük ve Mercimeklik yerleşmeleri bölge araştırmaları için önemlidir.

\section{Bölgede Yapılan Araştırmalar}

Banaz ilçesinde en erken yerleşim yeri son yıllarda tespit edilmiş olan ve Paleolitik döneme tarihlenen Sürmecik yerleşimidir. Sürmecik mevkiinde tesadüfen bulunan ve Orta Paleolitik döneme tarihlenen yerleşmede bir kurtarma kazısı yapılmaya başlanmıştır. Burası Banaz ilçesinin batısındaki seramik fabrikası yakınında, Kızılcaören Köyü’nün 2.5 km güneybatısında, Sürmecik (Uyuz) Hamamı olarak bilinen Paleolitik döneme ait açık hava konaklama yeridir. Yerleşmenin, büyük bir olasılıkla termal suların Paleolitik dönemde oluşturduğu bir bataklık ya da gölün kenarında kurulmuş bir açık hava yerleşimi olduğu değerlendirilmektedir. Sürmecik Paleolitik Çağ buluntuları, şimdiye kadar Ege Bölgesi’nde saptanan en zengin Paleolitik Çağ buluntu topluluğunu oluşturmaktadır. İnsanların Orta Paleolitik dönemde kesintisiz bir şekilde burada yaşadıkları anlaşılmaktadır. Mousterien kültürün tüm evrelerinin bir arada bulunduğu, çok karakteristik ve zengin yontmataş materyal ile sergilendiği bir açık hava yerleşimi şu ana kadar bilinmemekteydi. Bu durum hem Banaz (Uşak) hem Ege Bölgesi hem de Anadolu için de bir ilktir. Aletlerin tipolojik ve teknolojik özellikleri Homo Neanderthal insanlarının yaşadığı Orta Paleolitik dönemi ve mousterien kültürü işaret etmektedir. Sürmecik mevkii, şimdilik Uşak ilinin en eski yerleşim yeridir (Söyler vd., 2017, s. 384-388).

Bizim 2013 yılından itibaren gerçekleştirdiğimiz yüzey araştırmaları sonucunda bölgede Neolitik Çağdan itibaren yerleşimin var olduğu ortaya konulmuştur. Neolitik ve Kalkolitik Çağ yerleşmeleri az sayıda olmakla beraber özellikle yerleşim sayısı İTÇ'de artış göstermektedir (Oy, 2014, s. 215-230; Oy, 2016, s. 499-520). Banaz ilçesinde ise ovalık alanda olduğu kadar dağlık ve engebeli alanlarda da İlk Tunç Çağına ait yerleşmeler bulunmaktadır. Uşak Müzesi kayıtlarında Banaz ilçesindeki bazı Tunç Çağı yerleşimleri yer almaktadır (Uşak, 2007, s. 63-91).

$\mathrm{Bu}$ çalışmalar haricinde James Mellaart ve David French'in Batı Anadolu'da yaptığı yüzey araştırmalarında Uşak ilindeki bazı yerleşmeler kaydedilmiştir (Lloyd ve Mellaart, 1962, s. 196-197). Fakat Banaz ilçesi araştırılmamıştır. Ayrıca James Mellaart Banaz ilçesindeki bazı yerleşmelerden geldiği belirtilen tekil buluntulardan söz etmektedir. Bu tekil buluntu örneklerinin yerleri tam olarak belli değildir. Detaylı bilgi de verilmemiştir. Yine Banaz Ovasında Neolitik Çağ figürinlerinin tespit edildiği merkezlerin varlığı çeşitli yayınlarda geçmektedir (Mellaart, 1970, s. 173). 
Uşak ilinde bulunmuş olan bazı prehistorik eserler hakkında yapılan çalışmalarda bulunmaktadır. Çeşitli müze ve koleksiyonlarda bulunan figürinlerin yanı sıra Banaz İlçesi Alıçlı Höyük'e ait olduğu belirtilen ve Son Neolitik Çağ'a tarihlenen iki figürin de değerlendirilmektedir (Bilgi, 1980, s. 1-24).

Uşak’ta Sivaslı İlçesi’ndeki Selçikler'de yapılan kısa süreli kazılarda Kalkolitik Çağ buluntuları tespit edilmiştir. Fakat burası hakkında bilgiler kısıtlıdır (Fıratlı, 1970, s. 109-160; TAY/Selçikler). Uşak merkezde yer alan Altıntaş Höyük yerleşimi Son Neolitik ve İlk Kalkolitik Çağa tarihlenmektedir. Altıntaş Höyük’te belirlenen morumsu kırmızı astarlı seramikler Porsuk Kültürünün Uşak ilinde bu yerleşmeye kadar yayıldığını göstermektedir. Altıntaş Höyüğünün Son Neolitik Çağ buluntuları Göller Yöresi ve Batı Anadolu sahil kısımlarındaki merkezlerle ilişkilidir. İlk Kalkolitik Çağ buluntuları ise Afyonkarahisar ve Eskişehir-Kütahya yöreleriyle olan yakın ilişkiye işaret etmektedir (Oy, 2017a, s. $337)$.

Uşak iline komşu olan bölgelerde Neolitik ve Kalkolitik dönem yerleşmeleri hakkında araştırmalar gerçekleştirilmiştir. Banaz'a komşu olan Afyonkarahisar bölgesindeki yerleşmeler den Eyice Höyük Banaz'a oldukça yakın bir bölgede yer almaktadır (Koçak ve Bilgin, 2010, s. 24). Afyonkarahisar'da Son Neolitik ve İlk Kalkolitik Çağ yerleşmelerinin sayısı gittikçe artmaktadır (Koçak ve Bilgin, 2012, s. 1-10; Koçak ve Bilgin, 2013, s. 31-48). Kütahya çevresinde Aslanapa başta olmak üzere Kalkolitik Çağ yerleşmeleri önemlidir. Manisa'da Neolitik Çağ yerleşmeleri oldukça fazladır (Akdeniz, 2011, s. $1-46)$.

Denizli çevresinde Ekşi Höyük'te kazılar devam etmektedir. Sonuç olarak Ekşi Höyük kazıları, Yukarı Menderes Havzası'nın MÖ 7. Binyılın ilk yarısından itibaren yerleşilmiş olduğunu ortaya koymuştur. Ekşi Höyük’teki arkeolojik buluntular yerleşimin Göller Yöresi, Kıyı Ege ve kısmen Orta Anadolu ile ilişkilerini göstermektedir. Özellikle çanak çömlekler dikkate alındığında, bölgenin Göller Yöresi ile aynı kültür çevresi içerisinde yer aldığı söylenebilir (Dedeoğlu, Baysal, Ozan, Konakçı ve Temür, 2017, s. 553-568).

Ayrıca Denizli-Çivril ovasında erken döneme ait yerleşmeler tespit edilmiştir. Batı Anadolu'daki Ulucak, Yeşilova, Ege Gübre, Çukuriçi ve Dedecik-Heybelitepe kazıları sonucunda Neolitik ve Kalkolitik Çağ yerleşmeleri hakkında bilgilerimiz artmaktadır (Özdoğan, Başgelen, ve Kuniholm, 2012) (Harita 2).

\section{Ada Höyük}

Ada Höyük, Banaz'ın 16 km güneydoğusunda, Yazıtepe, Ayvacık ve Kavacık köylerinin arazilerinin kesiştiği noktada, Ayvacık köyü arazisinde kaldığı belirtilen Ada Mevkiinde bulunmaktadır. Ada Mevkii Kavacık köyünün 4 km kuzeyinde, Ayvacık köyünün 4 km güneydoğusunda, Ayvacık Göletinin $1 \mathrm{~km}$ güneydoğusunda, Yazıtepe köyünün $3 \mathrm{~km}$ güneybatısında, Çöğürlü köyünün $2 \mathrm{~km}$ kuzeydoğusunda bulunmaktadır (Resim 1). 
Ada Höyük olarak isimlendirdiğimiz bu yerleşim kuzey-güney uzantılı 200 metre ve doğu-batı uzantılı 100 metre kadardır. Doğal bir sırt üzerinde yer alan Ada Höyük Alıçlı Deresinin hemen batısında ve Kızılpınar Deresinin doğusunda bulunmaktadır. Yerleşme Alıçlı Deresi ve Kızılpınar Deresinin arasında Ada olarak adlandırılan doğal sırt üzerindedir. Tarla yolu yerleşmenin üzerinden geçmektedir. Yerleşme üzerinde Neolitik, Kalkolitik, İTÇ, Hellenistik ve Roma dönemi seramikleri ile obsidyenden yapılmış dilgi parçaları tespit edilmiştir (Oy, 2017b, s. 36; Oy, 2018, s. 45). Ada Höyük yerleşiminin Neolitik Çağ buluntuları oldukça zengindir (Resim 2-6). Ada Höyüğün bulunduğu bölge Neolitik Çağdan itibaren iskan edilmektedir. Bunun sebebi de bölgenin zengin su kaynaklarına sahip olması ve Afyonkarahisar-Hocalar arasındaki doğal yol üzerinde bulunmasıdır (Oy, 2017c, s. 85).

\section{Mercimeklik/Mercimekli Tepe}

Mercimeklik, Mercimeklik Mevkii veya Mercimekli Tepe olarak adlandırılan yerleşim Banaz'ın 20 km kadar kuzeydoğusundaki Paşacık köyünde bulunmaktadır (Resim 7). Paşacık köyünün 3.5 km doğusunda Mercimeklik Mevkiinde (Mercimekli Tepe) Kalkolitik, İTÇ ve Roma dönemi yerleşimi tespit edilmiştir (Resim 8). Yerleşme Afyonkarahisar-Uşak karayolunun 6-7 km güneyindedir. Etrafta rüzgar türbinleri bulunmaktadır. Höyük alanı doğu-batı doğrultulu 80 metre ve kuzey-güney doğrultulu 70 metre kadardır. Höyükteki yükseklik $8 \mathrm{~m}$ kadardır. Yerleşme üzerinde tarım yapıldığı için yüksekliği azalmaktadır. Höyüğün kuzeyi dik bir alandan oluşur. Yerleşmenin kıyısından tarla yolu geçmektedir. Yine yerleşmenin kıyısında küçük bir dere akmaktadır (Oy, 2017d, s. 73; Oy, 2018, s. 45-46).

Banaz’ın doğusunda Ahır Dağı eteklerine yakın bölgede bulunan Mercimeklik 1341 metre rakımda bulunmaktadır. Banaz'daki İTÇ yerleşmeleri içerisinde en düşük rakımda yerleşim 876 metre ile Susuz Höyük, en yüksek rakımda yerleşim ise 1341 metre ile Mercimeklik’tir. Bu durum bölgedeki yerleşimin oldukça yüksek rakımlara kadar çıktığını göstermesi bakımından önemlidir (Oy, 2018, s. $80)$.

Banaz ilçesinde yer alan çok sayıda İTÇ yerleşimi içerisinde kültürel olarak en erken yerleşim ilçenin güneydoğusunda Afyonkarahisar'a yakın bölgedeki Ada Höyük’tedir. Ada Höyük Neolitik, Kalkolitik ve İTÇ buluntuları ile ilçenin Sürmecik Orta Paleolitik yerleşiminden sonraki en erken yerleşimidir. Bir diğer erken dönem yerleşimi ise Mercimeklik/Mercimekli Tepe olup İlk Kalkolitik Çağda iskan görmüştür.

Ada Höyük Neolitik ve Kalkolitik Çağ buluntuları zengindir. Mercimeklik ise Kalkolitik Çă̆ buluntularıyla dikkat çekmektedir. Bu iki yerleşme Banaz'da tespit edilmiş̧ olan Sürmecik’ten sonraki en erken iki yerleşmedir. 


\section{4. Çanak Çömlek}

Burada 49 adet Neolitik ve Kalkolitik Çağ çanak çömleği değerlendirilmektedir (Levha 1-4). Buluntuların çoğunluğu Ada Höyük’ten toplanmış olup (46 adet) çok azı Mercimeklik'ten toplanmıştır (3 adet).

\subsection{Neolitik Çăg Çanak Çömleği}

Neolitik Çağ çanak çömleğinin tamamı (40 adet) Ada Höyük yerleşmesinden toplanmıştır (Çizim no: $1,5-13,15-21,23-28,30-41,45-49)$.

Neolitik Çağ çanak çömleği genel olarak kahverengi astarlı (31 adet), daha az oranda kırmızı astarlı ( 8 adet) ve gri astarlı (1 adet) mallardan oluşmaktadır. Neolitik Çağ seramiği açkılı olup genellikle iyi fırınlanmıştır. Hamurları kahverengi (17 adet), kırmızı (14 adet), gri (7 adet) ve siyah ( 2 adet) renkleri ve tonlarındadır. Katkı olarak en çok taşcık katkı belirlenmiştir (26 adet). Mika katkı (22 adet) ve kireç katk1 da yoğun olarak kullanılmıştır (22 adet). Bitki katkılar ise daha az oranda tercih edilmiştir (9 adet).

\subsubsection{Mal Grupları}

Neolitik Çağa tarihlenen 40 adet çanak çömlek içerisinde kahverengi, kırmızı ve gri olmak üzere 3 mal grubu belirlenmiştir.

Kahverengi astarlı mallar 31 adet olup 3/4 oranında büyük çoğunluğu oluşturmaktadır. Kahverengi astarlı malların hamurlarında taşcık (21 adet), mika (17 adet), kireç (15 adet) ve bitki ( 7 adet) katkılar bulunmaktadır. Bu grup mallarının hamur renkleri de kahverengi (14 adet), kırmızı (11 adet) ve gri (6 adet) tonlarına sahiptir. Bu grup mallarının çok büyük kısmı açkılı olup ( 28 adet) çok azı ise açkısızdır (3 adet).

Kırmızı astarlı mallar 8 adet olup ikinci büyük grubu oluşturmaktadır. Bu grup mallarının hamurlarında kireç ( 7 adet), taşcık (5 adet) mika (4 adet) ve bitki ( 2 adet) katkılar vardır. Hamur rengi ise kırmızı ( 3 adet), kahverengi ( 3 adet) gri ( 1 adet) ve siyah ( 1 adet) tonlarındadır. Bu grup mallarının biri hariç tamamı açkılıdır.

Diğer grubu oluşturan tek bir parça ise gri astarlı olup ayrı bir mal grubu olarak değerlendirilmiştir. Açkısız olan ve orta derecede fırınlanmış olan bu parçanın hamuru siyah renktedir ve hamurunda yoğun mika katkı yer almaktadır.

\subsubsection{Kap Formları}

Neolitik Çağ kapları açık ve kapalı formlardan oluşmaktadır. Açık formlar içerisinde hafif "S" profilli (no: 1), basit ağızlı ve sı̆̆ (no: 5), dışa çekik ağızlı ve dar uzun boyunlu (no: 6) örnekler bulunmaktadır. Çoğunluğu ise kapalı formlar oluşturmaktadır. Bu formlar içerisinde kısa boyunlu ve şişkin gövdeli (no: 7), kapalı dar ağızlı ve şişkin gövdeli (no: 8-13), kısa boyunlu ve derin gövdeli (no: 
15-19), basit ağızlı ve dik gövdeli (no: 20-21, 23-26), dışa dönük ağızlı ve kısa boyunlu (no: 27-28), dışa dönük ağızlı ve dar boyunlu (no: 30-33) gibi örnekler belirlenmiştir. Ayrıca Neolitik Çağa tarihlenen kulp örnekleri de bulunmaktadır (no: 34-38). Kulplar içerisinde dikey kulp (no: 34-35), sepet kulp (no: 36-37) ve ip delikli tutamak (no: 38) örnekleri vardır. Yine Neolitik Çağa tarihlenen düz dipler de mevcuttur (no:45-49). Hafif "S" profilli kase (no:1), Hacilar VI, Hacilar VIII (Son Neolitik Çağ) (Mellaart, 1970, s. 253/1-3; 247/16), Hacılar IIA ve IIB (İlk Kalkolitik Çağ) (Mellaart, 1970, s. 331/31), Yeşilova Höyüğü III. 3 tabaka kaseleri (Neolitik II-MÖ 6250-6000) (Derin vd., 2009, s. 40, fig. 11/52) ile benzemektedir.

Açık formların benzerini (no: 5) Kuruçay Höyük Erken Kalkolitik Çağ katlarında (7. Kat A2 seramiği) (Duru, 1994, Levha 167/3), Hacılar III (İKÇ) açık formlarında (Mellaart, 1970, s. 293/2), Yeşilova Höyüğü III. 3 tabaka (MÖ 6250-6000, Neolitik II) (Derin, Ay, Caymaz, 2009, s. 40, fig. 11/55), Manisa Yöresi Neolitik Çağ yerleşmelerinden Akhisar ve Moralılar yerleşmelerindeki kapalı formlarla (Akdeniz, 2011, s. 41, fig. 13), ayrıca Yukarı Menderes Vadisi Neolitik ve Erken Kalkolitik Çağ yerleşmelerinde (Dedeoğlu, 2014, s. 54, fig. 4/6) tespit edilen örneklerde görmek mümkündür.

Kapalı ağızlı ve şişkin gövdeli çömleklerin benzerleri (no: 8-13), Kuruçay Geç Neolitik Çağ katlarında (11. Kat üst A1 seramiği) (Duru, 1994, Levha 71/1), Demircihöyük A ve E arası malları (Neolitik ve İlk Kalkolitik Çağ) içerisinde (Seeher, 1987, Tafel 2-11), Ulucak Höyük Geç Neolitik Çağ kaplarında (Derin ve Öner, 1997, s. 431, çizim 1/4; Çilingiroğlu ve Abay, 2005, s. 17, fig. 12/9), Yeşilova III. 6 katları (MÖ 6250 Neolitik I) (Derin vd., 2009, s. 37, fig. 8/20) ve Çukuriçi Höyük IX (Geç Neolitik) (Horejs, 2012, s. 131, fig. 10/B) katlarında bulunmaktadır. Kısa boyunlu ve derin gövdeli (no: 15-19) formu Fındıkkayabaşı (Neolitik) derin çömlekleri (Efe, 1995, s. 107, 112, resim 2/1-3) ve Denizli, Selcen Örenarası çömlekleriyle benzemektedir (Dedeoğlu ve Ozan, 2016, s. 29, fig. 11/b). Basit ağızlı ve dik gövdeli (no: 20-21, 23-26) formların benzerlerini Hacılar IX (Son Neolitik Çağ) (Mellaart, 1970, s. 241/14-15), Ulucak Höyük Geç Neolitik Çağ kaplarında (Ulucak V) (Çilingiroğlu ve Abay, 2005, s. 17, fig. 12/7-8), Manisa Yöresinde Moralılar yerleşmesinde (Akdeniz, 2011, s. 42, fig. 19), Yukarı Menderes Vadisi Neolitik ve Erken Kalkolitik Çağ yerleşmelerinde (Dedeoğlu, 2014, s. 54, fig. 4/15-16) bulunmaktadır.

Kapalı dar ağızlı ve şişkin gövdeli (no: 8-13) formlar ile dışa dönük ağızlı ve kısa boyunlu (no: 27-28), dışa dönük ağızlı ve dar boyunlu (no: 30-33) formların benzerlerini Hacılar IIA (IKKÇ) katında bulmak mümkündür (Mellaart, 1970, s. 305-307). Yine kapalı ve küresel gövdeli örnekleri Akmakça'da (Efe, 1995, s. 113, resim 3/6), Yeşilova Höyüğü tabaka III. 3 (MÖ 6250-6000, Neolitik II) ve III. 1-2 tabakada (MÖ 6000-5800, Neolitik III) (Derin vd., 2009, s. 40, fig. 11/53; fig. 12/62), Manisa Yöresinde Moralılar ve Refik Aslan Tepe yerleşmelerinde (Akdeniz, 2011, s. 43, fig. 27-29), Denizli Ekşi Höyük Neolitik-Erken Kalkolitik MÖ 6400-6000 ve MÖ 6000-5700 yıllarına tarihlenen yapı katı kaplarında vardır (Dedeoğlu vd., 2017, s. 564, fig. 6; s. 566, fig. 9). Dişa dönük ağızlı ve kısa boyunlu (no: 27-28) örneklerin benzerleri Demircihöyük E türü malları ile benzerdir (Seeher, 1987, Tafel 13/1- 
4). Ayrıca Yukarı Menderes Vadisi Neolitik ve Erken Kalkolitik Çağ yerleşmelerinde benzerleri görülmektedir (Dedeoğlu, 2014, s. 52, fig. 2/7).

Düz diplerin yakın benzerlerini (no: 45-49) Kuruçay Geç Neolitik Çağ katları (11. Alt, A2 seramiği) (Duru, 1994, Levha 61/12-13), Kuruçay Erken Kalkolitik Çağ katları (7. Kat A2 seramiği) (Duru, 1994, Levha 167/9), Hacılar IX (Son Neolitik Çağ) (Mellaart, 1970, s. 245/34), Höyücek Kutsal Alanlar Dönemi çanak çömleği diplerinde (KAD mal 3) (Duru ve Umurtak, 2005, Levha 79/1-6), Demircihöyük A malları ile E malları (Neolitik ve İlk Kalkolitik Çă̆) (Seeher, 1987, Tafel 1/15; Tafel 3/10-13; Tafel 16/1-15), Orman Fidanlığ1 I-IV (İlk Kalkolitik Çağ) (Efe, 2001, s. 100, fig. 12/215), Yukarı Menderes Vadisi Neolitik ve Erken Kalkolitik Çağ yerleşmelerinde bulmak mümkündür (Dedeoğlu, 2014, s. 53, fig. 3/23-25; fig. 5/20-21).

Sepet kulplara (no: 36-37) Kuruçay Geç Neolitik Çağ katlarında (11. Kat E keramiği) (Duru, 1994, Levha 67/5-6), Ada Höyüktekilerden biraz farklı olsa da Hacılar IX (Son Neolitik Çağ) (Mellaart, 1970, s. 245/39) katlarında, Demircihöyük B malları içerisinde (Neolitik ve İlk Kalkolitik Çağ) (Seeher, 1987, Tafel 3/20-21), Orman Fidanlığı I-II (İlk Kalkolitik Çağ) (Efe, 2001, s. 91, fig. 3/36), hem sepet kulp hem de tutamak bulunan örneklere Höyücek Tapınak Dönemi (Erken Neolitik Çağ) TD mal 3 çanak çömleği içerisinde bulunmaktadır (Duru ve Umurtak, 2005, Levha 58/2-3). Çatalhöyük-Batı (Erken Kalkolitik Çağ I-II) örnekleri içerisinde de benzer örnekler vardır (Mellaart, 1965, 148, fig. 11/17). İp delikli tutamak (no: 38) ise Demircihöyük B malları ile benzerdir (Seeher, 1987, Tafel 4/15).

\subsubsection{Bezemeler}

Neolitik Çağ kaplarının bazılarında bezemeler yer almaktadır. Bunlardan dışa çekik ağızlı ve dar uzun boyunlu kabın boyun kısmında bir delik bulunmaktadır (no: 6). Kapalı formlar genellikle bezemesiz olmakla beraber bazılarında bezemeler yer alır (no: 24). Dik gövdeli bir kabın yüzeyinde konsantrik daire şeklinde bezeme vardır (no: 24). Konsantrik dairenin içi sivri uçlu bir aletle oluşturulmuştur. Yuvarlak gövde üzerinde bir delik mevcut olan örnek bulunmaktadır (no: 40). Yine yuvarlak gövde üzerinde üç tane yuvarlak kabartmadan oluşan bezemeli bir parça da bulunur (no: 41).

Konsantrik daire şeklindeki bezemenin benzerini Demircihöyük $\mathrm{C}$ mallarında görmek mümkündür (Seeher, 1987, Tafel 7/32). Bu tür mallar Demircihöyük'te Fikirtepe mallarına benzerliğinden dolayı ayrı bir grup olarak ele alınmıştır. Demircihöyük’teki konsantrik daire kalın cidarlı bir kaba ait olup gövde üzerinde yer almaktadır. Profil belli değildir. Ada Höyük’teki örneğin profili ise dik gövdeli bir kaba aittir.

\subsection{Kalkolitik Çağ Çanak Çömleği}

Kalkolitik Çağ çanak çömleği 9 adettir. Çoğunluğu (6 adet) Ada Höyük yerleşmesinden olup 3 tanesi Mercimeklik/Mercimekli Tepe yerleşmesinden toplanmıştır (çizim no: 2-4, 14, 22, 29, 42-44). Bu grupta yer alan çanak çömlekler boya bezemelidir. Sayı olarak az olmasına karşın astar renkleri 
bakımından zengindir. Kahverengi astarlı ( 3 adet), beyaz ( 3 adet), pembe ( 2 adet) ve mor astarlı (1 adet) mal grupları belirlenmiştir. Hamurlarda katkı olarak kireç ( 7 adet), mika (4 adet) ve taşcık (1 adet) katkılar vardır. Hamur renkleri de çeşitli olup kahverengi ( 4 adet), gri ( 3 adet) kırmızı (1 adet) ve siyah ( 1 adet) hamur renkleri belirlenmiştir. Bu mal grubunun yüzeyleri tamamen açkılıdır.

\subsubsection{Mal Grupları}

Kalkolitik Çağ çanak çömleğinde 4 mal grubu belirlenmiştir. Kahverengi astarlı ( 3 adet), beyaz astarlı ( 3 adet), pembe astarlı ( 2 adet) ve mor astarlı ( 1 adet) mallardan oluşan ve boya bezemeli olan gruptur.

Kahverengi astarlı mallar 3 adet olup hamurunda kireç ve mika katkılar yer almaktadır. Hamur renkleri ise birbirinden farklı olup kırmızı, kahverengi ve gri hamur renklerine sahiptir. Beyaz astarlı mallar 3 adet olup hepsinin hamurunda kireç katkı vardır. Sadece birisinde taşcık katkı katılmıştır. Açkılı olan bu grup mallarının hamurları kahverengi ( 2 adet) ve gri (1 adet) renklidir. Bu grup mallarının 2 tanesinin iç kısmı astarsızdır. Pembe astarlı mallar 2 adetle temsil edilmektedir. Hamurları kahverengi ve gri tonlarında olup mika ve kireç katkılar vardır. Mor astarlı mal 1 tane ile temsil edilmektedir. Mika katkılı olan bu malın hamuru siyah renklidir.

\subsubsection{Kap Formları}

Kalkolitik Çağa ait belirlenen formlar açık ve kapalı kaplara ait olup boya bezemeli örneklerden oluşmaktadır. Açık formlar içerisinde minyatür olan kaplarda bulunmaktadır (no: 2-4). Bu kapların iç ve dış yüzeyleri boya bezemelidir. Dışa açık, sivri ağızlı (no: 14) ve dik gövdeli (no: 22) örneklerde vardır. Dışa dönük ağızlı ve kısa boyunlu (no:29) örnekler ile boya bezemeli yuvarlak gövdelere ait örnekler de vardır (no: 42-44).

\subsubsection{Bezemeler}

Kalkolitik Çağa ait kaplarda boya bezemeler kullanılmıştır. Boya bezemeler bazı kapların hem iç hem dış yüzeyine uygulanmıştır (no: 2-4). Diğerlerinde sadece dış yüzeye boya bezeme uygulanmıştır. (no: 14, 22, 29, 42-44). Boya bezemeler, krem astar üzerine kırmızı boya bezemeli (no: 3-4, 29, 42-43), mor astar üzeri krem boya bezemeli (no:22), beyaz astar üzeri kırmızı boya bezemeli (no: 44) gibi örneklerden oluşur. Boya bezemeler dikey, yatay, çapraz bant bezeme veya yarım daire şeklinde bezemelidir. Bazı boya bezemeli kapların iç kısmında astar yoktur (no: 43-44). Dikey bant bezemeli (no: 4) kabın benzeri Kuruçay Erken Kalkolitik Çağ (8. Kat A1 seramiği) (Duru, 1994, Levha 158/1) ile bant bezemeli olan (no: 42) örneğin benzeri Hacılar I (IKKÇ) krem astar üzeri kırmızı boya bezemeli örnekleriyle (Mellaart, 1970, s. 160, 421/Level I), diğer boya bezemelilerin benzerlerini (no: 42-44) Afyonkarahisar Üçin'de görmek mümkündür (Koçak ve Bilgin, 2013, s. 47, resim 12/5).

\section{Değerlendirme Ve Sonuç}

Uşak ilinin doğusunda Banaz'da yer alan Ada Höyük ve Mercimeklik yerleşmeleri Sürmecik Orta Paleolitik yerleşmesinden sonra bölgedeki en erken iki yerleşim yeridir. Ada Höyük Son Neolitik/ilk 
Kalkolitik Çağa, Mercimeklik ise İlk Kalkolitik Çağa tarihlenmektedir. Banaz'da ki bu iki yerleşme Uşak ilindeki az sayıda Neolitik ve İKÇ yerleşmesi düşünüldügünde ve konumları göz önüne alındığında bölgenin erken dönemlerinin aydınlatılmasında önem arz etmektedir. Uşak ve Banaz İçbatı Anadolu'da Orta Anadolu ile Batı Anadolu kıyı kesimleri arasında bağlantıyı sağlayan bir konumda olduğu gibi güneydeki Göller Yöresi ile kuzeydeki Fikirtepe kültürleri arasında kalan bir bölgede yer almaktadır. Banaz'daki Ada Höyük yerleşimi Son Neolitik Çağ ve İlk Kalkolitik Çağa tarihlenen buluntular vermektedir. Mercimeklik ise ilk Kalkolitik Çağa ait buluntular ile bölge açısından önemli olan merkezlerdir.

Ada Höyük ve Mercimeklik Banaz Ovasının kıyısındaki dağlık ve engebeli alanda yer alan ortalama 1100-1300 m yükseklikte konumlanmış yerleşmelerdir. Ovalık alanda çok sayıda İTÇ yerleşimi belirlenmiştir. Banaz Ovasının alüvyal dolguları düşünüldüğünde İTÇ tabakaları altında ve ova seviyesine inildikçe Neolitik ve Kalkolitik Çağa ait yeni bulgulara ulaşılması olasıdır. Şimdilik Banaz Ovasında Neolitik ve Kalkolitik yerleşmeler tespit edilememiştir. Aynı şekilde Sürmecik Paleolitik buluntuları toprak dolgunun 15-20 m kadar kazılması sonucunda tesadüfen ortaya çıkarılmıştır. Benzer durumların Banaz Ovasında da yaşanması ihtimali kuvvetlidir.

Yerleşmelerdeki Son Neolitik Çağ kap formları içerisinde kapalı ağızlı ve derin kaplar çoğunluktadır. Sığ kaplar ise daha azdır. Ayrıca minyatür kaplarda vardır. Sepet kulp ve ip delikli tutamak örnekleri belirgindir. Dipler düzdür. Son Neolitik Çă̆ kapları genellikle bezemesiz olmakla beraber boya bezeme, delik ve kabartma bezemeli örneklerin varlığı farklı bezemelerin uygulandığını ortaya koymaktadır. Özellikle konsantrik daire bezemeli olan örnek (no: 24) kuzeyde bulunan Fikirtepe kültürünün tipik çizi bezemeli kaplarını akla getirmiş olsa da bu kültürle ilişki kuracak kadar fikir verememektedir.

Banaz'daki Son Neolitik Çağ kaplarının Göller Yöresi ile olan ilişkisi ise oldukça belirgindir. Ayrıca Batı Anadolu kıyıları ve kuzeydeki Kütahya bölgesi ile de ilişkiler mevcuttur. Orta Anadolu ile ilişkiler ise daha azdır.

İlk Kalkolitik Çă̆ kapları genellikle boya bezemeli örneklerden oluşmaktadır. Krem astar üzeri kırmızı boya bezemeli örnekler Göller Yöresi ile olan güçlü ilişkileri vurgulamaktadır. Yine yakın çevrede yer alan Afyonkarahisar ile olan ilişkiler vardır. Morumsu kırmızı astarlı örneklerin varlığı kuzeydeki Aslanapa kültürünün Uşak ilindeki yayılımını göstermesi bakımından önemlidir. Nitekim morumsu kırmızı astarlı örnekler Uşak merkezdeki Altıntaş Höyük yerleşiminde de tespit edilmiştir. Aslanapa morumsu kırmızı astarlı mallarına Uşak Ovasının güneyine doğru uzanan bölgedeki Adatepe yerleşiminde de rastlanıldığı belirtilmiştir (Efe, 2001, s. 58). Banaz'da olduğu kadar Uşak ovasında da bu tür örneklerle karşılaşılması bu mal grubunun güneydeki yayılım alanını göstermesi bakımından önemlidir. Uşak bölgesinde Aslanapa morumsu kırmızı astarlı mallarının yanı sıra Göller Yöresi ve Hacılar kültürü mallarının da bulunuyor olması Uşak bölgesinin kuzeydeki ve güneydeki kültür 
bölgeleri ile ilişkili bir bölgede olmasından kaynaklanmaktadır. Bu kültür bölgelerinin yayılım alanı ve sınırlarının belirlenmesinde Uşak bölgesindeki yerleşmeler önemlidir.

Göller Yöresi, Fikirtepe, Batı Anadolu kıyıları ile Orta Anadolu'daki Neolitik ve İKÇ kültürel bölgelerinin kesiştiği bir bölgede yer alan Uşak ve çevresinde yapılacak araştırmaların artması ile bu kültür bölgelerinin Uşak bölgesi ile olan ilişkisi ve bağlantıları, ayrıca etkileşimleri ve kültürel sınırların anlaşılması bakımından önemli sonuçlara ulaşılacaktır.

Afyonkarahisar'ın batısında Uşak sınırına ve Banaz'a yakın olan Eyice Höyük yerleşimi Ada Höyük ve Mercimeklik yerleşimine çok yakındır. Mercimeklik ile Eyice Höyük arası kuş uçumu $20 \mathrm{~km}$ kadardır. Yine Mercimeklik ile Aslanapa arasında kuş uçumu $50 \mathrm{~km}$ kadar mesafe söz konusudur. Aslanapa ile Mercimeklik arasında Murat Dağı bulunmakta olup Murat Dağının doğusundan dolaşarak iki yerleşim birbiriyle bağlantıyı sağlayacak durumdadır. Ada Höyük ile Mercimeklik yerleşimi arasında kuş uçumu 20 km mesafe vardır. İki yerleşmede Banaz'ın doğusunda Afyonkarahisar sınırına yakın bir konumdadır. Mercimeklik Banaz'ın kuzeydoğusunda Afyonkarahisar ve KütahyaDumlupınar'a yakın bir noktadadır. Ada Höyük Banaz'ın güneydoğusunda Afyonkarahisar'ın Hocalar ve Sandıklı ilçelerine yakın bir konumdadır. Ada Höyügün kuş uçumu 65 km kuzeyinde KütahyaAslanapa yer alır. Ada Höyüğün 40 km kuzeydoğusunda Afyonkarahisar-Eyice Höyük vardır. Bu yerleşmelerin bu kadar yakın olması kültürel bakımdan da bir etkileşimin var olmasını desteklemektedir.

Uşak ili kuzeydeki Aslanapa bölgesi ile komşudur. Uşak merkezde yer alan Altıntaş Höyük yerleşimi Aslanapa kültürünün etkisindedir. Uşak Altıntaş Höyük ile Ada Höyük arasında $30 \mathrm{~km}$ kadar bir uzaklık vardır. Mercimeklik ile Uşak Altıntaş Höyük arasında 40 km mesafe vardır. Bu üç yerleşmede Aslanapa kültürünün morumsu kırmızı astarlı malları tespit edilmiştir. Aslanapa kültürü ile Uşak’taki Son Neolitik ve İlk Kalkoltik Çağ yerleşmeleri arasında Murat Dağı yer alır. Bu dağ Kütahya ve Uşak illerini ayırmış olsa da kültürel olarak Aslanapa kültürü Murat Dağının güneyindeki Uşak bölgesinde geniş bir alana yayılım göstermektedir.

Uşak’ın güneyindeki Denizli Ekşi Höyük kazıları, Yukarı Menderes Havzası'nın MÖ 7. Binyılın ilk yarısından itibaren yerleşilmiş olduğunu ortaya koymuştur. Ekşi Höyük’teki arkeolojik buluntular bu yerleşimin Göller Yöresi, Kıyı Ege ve kısmen Orta Anadolu ile ilişkilerini göstermektedir. Özellikle bölgenin Göller Yöresi ile aynı kültür çevresi içerisinde yer aldığı değerlendirilmektedir (Dedeoğlu vd., 2017, s. 559). Uşak ve Banaz çevresindeki Son Neolitik ve İlk Kalkolitik Çağ yerleşmeleri de güneydeki komşusu Denizli ve Yukarı Menderes Vadisi ile bağlantılıdır. Ada Höyük güneydeki Denizli, Çivril Ovasına 40-50 km mesafede, Denizli ve Yukarı Menderes Vadisine de yakın bir konumdadır. Yine Ada Höyük Göller Yöresi, Hacılar ve Kuruçay’a kuş uçumu 120 km mesafedir. Bu yakın bölgelerde yer alan yerleşmelerin karşıllklı ilişkilerinin kültürel olarak az veya çok olması kaçınılmazdır. 


\section{Kaynakça}

Akdeniz, E. (2011). “Neolitik Çağ'da Manisa Yöresi”, OLBA, XIX, 1-46.

Bilgi, Ö. (1980). "Yeni Bulunmuş Eserlerin Işığı Altında Anadolu'da Bronz Çağı Öncesi İnsan Figürleri Hakkında Yeni Gözlemler”, Belleten, XLIV/173, 1-24.

Çilingiroğlu, A. ve Abay, E. (2005). "Ulucak Höyük Excavations: New Results", Mediterranean Archaeology and Archaeometry, 5 (9), 5-21.

Dedeoğlu, F. (2014). "Yukarı Menderes Havzası Neolitik ve Erken Kalkolitik Çağ Yerleşimlerinin Materyal Kültür Ve İskân Düzeni Bağlamında Değerlendirilmesi”, Pamukkale Üniversitesi Sosyal Bilimler Enstitüsü Dergisi, 18, 33-56.

Dedeoğlu, F. ve Ozan, A. (2016). "What Happened in Inland Southwestern Anatolia Before 5500 BC? A Review of the Archaeological Evidence from the Selcen-Örenaras1 Settlement", OLBA, XXIV, 130.

Dedeoğlu, F. Baysal, H. H. Ozan, A. Konakçı, E. ve Temür, B. (2017). “Ekşi Höyük 2016 Yı1ı Kazı Çalışmaları”, Kazı Sonuçları Toplantısı, 39 (1), 553-568.

Derin, Z. ve Öner, E. (1997). "Ulucak Höyük Kazıları ve Paleo-Coğrafya Araştırmaları", Kazı Sonuçları Toplantısı, XVIII/I, 411-439.

Derin, Z. Ay, F. Caymaz, T. (2009). “İzmir'in Prehistorik Yerleşimi-Yeşilova Höyüğü 2005-2006 Y11ı Çalışmaları”, Arkeoloji Dergisi, XIII/1, 1-58.

Duru, R. (1994). Kuruçay Höyük I, 1978-1988 Kazılarının Sonuçları Neolitik ve Erken Kalkolitik Çağ Yerleşmeleri, Ankara: TTK Basımevi.

Duru, R. ve Umurtak, G. (2005). Höyücek 1989-1992 Yılları Arasında Yapılan Kazıların Sonuçları, Ankara: TTK Yayınları.

Efe, T. (1995). “İç Batı Anadolu'da İki Neolitik Yerleşme: Fındık Kayabaşı ve Akmakça”, Memoriam İ. M. Akyurt-B. Devam Anı Kitabı/ Eski Yakın Doğu Kültürleri Üzerine İncelemeler, (ed. A. Erkanal, H. Erkanal, H. Hüryılmaz ve A. Tuba Ökse), İstanbul: Arkeoloji ve Sanat Yayınları, 105-114.

Efe, T. (2001). The Salvage Excavations at Orman Fidanlığı A Chalcolithic Site in Inland Northwestern Anatolia, İstanbul: TASK Vakfi Yayınları.

Horejs, B. (2012). "Çukuriçi Höyük A Neolithic and Bronze Age Settlement in the Region of Ephesos", The Neolithic in Turkey New Excavations \& New Research, Vol. 4 Western Turkey, (ed: M. Özdoğan, N. Başgelen ve P. Kuniholm), İstanbul: Arkeoloji Sanat Yayınları, 117-131.

Koçak, Ö. ve Bilgin, M. (2010). “Afyonkarahisar’da İki Önemli Son Neolitik/İk Kalkolitik Yerleşme Yeri: Eyice ve Pani Höyük", TÜBA-AR, 13, 9-38. 
Koçak, Ö. ve Bilgin, M. (2012). "İçbatı Anadolu Bölgesinde Geç Neolitik ve Erken Kalkolitik Çağa Ait Yeni Yerleşmeler”, Höyük, 5, 1-10.

Koçak, Ö. ve Bilgin, M. (2013). “Afyonkarahisar Üçin Buluntuları Işı̆̆ında Batı Anadolu Prehistoryası Üzerine Yeni Gözlemler”, Adalya, XVI, 31-48.

Fıratl1, N. (1970). "Uşak Selçikler Kazısı ve Çevre Araştırmaları", Türk Arkeoloji Dergisi, XIX/II, 109-160.

Lloyd, S. ve Mellaart, J. (1962). Beycesultan I, The Chalcolithic and Early Bronze Age Levels, , London: British Institute of Archaeology at Ankara Occasional Publication.

Mellaart, J. (1965). “Çatal Hüyük West”, Anatolian Studies, 15, 135-156.

Mellaart, J. (1970). Excavations at Hac1lar I-II, Edinburgh.

Munsell (2015). Munsell Soil-Color Book 2009 Year Revised/2015 Production, Michigan.

Oy, H. (2014). "Uşak İli ve İlçelerinde İlk Tunç Çağı Coğrafya Araştırmaları 2013 Yılı Çalışmaları", Araştırma Sonuçları Toplantısı, 32 (1), 215-230.

Oy, H. (2016). "Uşak İli Merkez İlçe İlk Tunç Çağı Araştırmaları 2014 Yılı Çalışmaları", Araştırma Sonuçları Toplantıs1, 33(29), 499-520.

Oy, H. (2017a). "Uşak İli’nde Bulunan Neolitik ve Kalkolitik Bir Yerleşim: Altıntaş Höyük”, Süleyman Demirel Üniversitesi Sosyal Bilimler Enstitüsü Dergisi, Yı1: 2017/3, Sayı:28, 337-358.

Oy, H. (2017b). "Uşak İli Tunç Çağı Araştırmaları", İçinde: Yüzey Araştırmaları ve Kazılar Işı̆̆ında Uşak, (Ed: R. M. Czichon, Ş. Söyler, B. Can ve İ. Çavuş), İstanbul: Zero Production, 33-38.

Oy, H. (2017c). "Banaz'da Bir Tunç Çağı Yerleşimi: Ayvacık Höyük”, Asos Journal, The Journal of Academic Social Science, Akademik Sosyal Araştırmalar Dergisi, Y11 5, Say1 50, 74-93.

Oy, H. (2017d). "Uşak-Banaz İlk Tunç Çağı Araştırmaları 2015 Yılı Çalışmaları", Araştırma Sonuçları Toplantısı, 34 (1), 51-74.

Oy, H. (2018). İlk Tunç Çă̆ı'nda Uşak 1, (Merkez, Banaz ve Sivaslı İlçeleri), Ankara: Gece Kitaplığı. Özdoğan, M. Başgelen, N. ve P. Kuniholm. (2012). The Neolithic in Turkey New Excavations \& New Research, Vol. 4 Western Turkey, İstanbul: Arkeoloji Sanat Yayınları.

Seeher, J. (1987). Demircihüyük III/1, Mainz am Rhein.

Söyler, Ş. Taşkıran, H. Czichon, R. M. Özçelik, K. Polat, S. Yılmaz, M. A. Erbil, E. Türker, M. ve D. Dağcı. (2017). “Uşak Banaz Sürmecik Paleolitik Kazısı-2016”, Kazı Sonuçları Toplantısı, 39 (2), 381391.

TAY Türkiye Arkeolojik Yerleşmeleri 
Uşak, (2007). Uşak Kültürel Değerler Yapı Envanteri, Uşak Valiliği İl Kültür ve Turizm Müdürlügü Yayını, İzmir: Neşa Ofset.

Yalçınlar, İ. (1955). "Banaz Çayı Havzası ve Uşak Civarında Bünye ve Morfoloji Araştırmaları”. Türk Coğrafya Dergisi, 13-14, 57-85.

\section{Katalog}

\section{Levha 1}

1. Ada Höyük: "S" profilli kase parçası, el yapımı, açkılı, iyi pişmiş, iç kısımda alacalanma var, taşcık, kireç katkıl1, yüzey: 10 R 4/8 red, hamur: 2.5 YR 4/4 reddish brown.

2. Ada Höyük: Minyatür kap parçası, el yapımı, açkı1l, iyi pişmiş, kireç, mika katkılı, dış yüzey: 5 YR 5/3 reddish brown, iç yüzey: 7.5 R 6/6 light red, hamur: 7.5 R 5/6 red. Ağız iç kısmında boya bezeme var. Boya bezeme: 5 R 3/6 dark red.

3. Mercimeklik: Minyatür kap parçası, el yapımı, açkılı, iyi pişmiş, kireç katkılı, iç ve dış yüzey astarl. Yüzey: White 7.5 YR/1 9/ White, boya bezeme:10 R 5/4 weak red, hamur: Gley 1 5/ gray. (krem astar üzeri kırmızı boya bezemeli). Ağız iç kısmında bant boya bezeme var. Dış yüzeyde iç içe yarım daire şeklinde boya bezme var.

4. Ada Höyük: Minyatür kap parçası, el yapımı, açkı1l, iyi pişmiş, kireç, mika katkılı, yüzey: 7.5 YR 6/4 light brown, hamur: 7.5 YR 6/4 light brown. İç ve diş yüzeyde boya bezeme var. Boya bezeme: 10 R 5/6 red. (krem astar üzerine kırmızı boya bezemeli).

5. Ada Höyük: Kase parçası, el yapımı, açkı11, iyi pişmiş, kireç katkı1ı, yüzey: 5 YR 6/3 light reddish brown, hamur: 2.5 YR 4/6 red.

6. Ada Höyük: Uzun boyunlu çömlek parçası, el yapımı, açkısız, orta pişmiş, yoğun mika katkıl1, yüzey: Gley 2 3/1 very dark bluish gray, hamur: Gley 1 2.5/ black. Ağız üstünde delik var.

7. Ada Höyük: Çömlek parçası, el yapımı, açkılı, iyi pişmiş, bitki, yoğun taşcık katkılı, yüzey: 5 YR 5/4 reddish brown, hamur: Gley 2 3/1 very dark bluish gray.

\section{Levha 2}

8. Ada Höyük: Kapalı ağızlı çömlek parçası, el yapımı, açkılı, iyi pişmiş, bitki, mika, taşcık katkıl1, yüzey: 5 YR 5/4 reddish brown, hamur: 5 YR 4/6 yellowish red.

9. Ada Höyük: Kapalı ağızlı çömlek parçası, el yapımı, açk1lı, iyi pişmiş, bitki, taşc1k, mika katkılı, yüzey: 10 YR 3/2 very dark grayish brown, hamur: 5 YR 4/4 reddish brown.

10. Ada Höyük: Kapalı ağızlı çömlek parçası, el yapımı, silik açkılı, iyi pişmiş, kireç, mika katkılı, yüzey: 5 YR 6/4 light reddish brown, hamur: 10 R 5/6 red. 
11. Ada Höyük: Kapalı ağızlı çömlek parçası, el yapımı, açkılı, iyi pişmiş̧, yoğun mika katkı1l, yüzey: 2.5 YR 5/4 reddish brown, hamur: Gley 2 3/1 very dark bluish gray.

12. Ada Höyük: Kapalı ağızlı çömlek parçası, el yapımı, açkıl1, iyi pişmiş, taşcık katkılı, yüzey: 2.5 YR 5/4 reddish brown, hamur: 7.5 YR 5/3 brown.

13. Ada Höyük: Kapalı ağızlı çömlek parçası, el yapımı, silik açkılı, iyi pişmiş, taşcık, mika katkılı, yüzey: 7.5 YR 5/4 brown, hamur: 2.5 YR 4/4 reddish brown.

14. Ada Höyük: Çömlek parçası, el yapımı, açkıl1, iyi pişmiş, kireç katkıl1, yüzey: 7.5 YR 6/3 light brown, hamur: Gley 1 5/ gray. Dış yüzeyde boya bezeme var. Boya bezeme: 10 R 4/6 red.

15. Ada Höyük: Çömlek parçası, el yapımı, açkı1lı, iyi pişmiş, mika, taşcık, kireç katkı1lı, yüzey: $10 \mathrm{R}$ 4/6 red, hamur: 2.5 YR 5/4 reddish brown.

16. Ada Höyük: Çömlek parçası, el yapımı, açkısız, iyi pişmiş, taşcık, kireç, mika katkılı, yüzey: 5 YR 6/4 light reddish brown, hamur: 7.5 YR 4/4 brown.

17. Ada Höyük: Çömlek parçası, el yapımı, açkısız, iyi pişmiş, bitki, taşcık, mika katkılı, yüzey: 5 YR 6/4 light reddish brown, hamur: 5 YR 6/3 light reddish brown.

18. Ada Höyük: Çömlek parçası, el yapımı, açkılı, iyi pişmiş, taşcık, mika katkılı, yüzey: 7.5 YR 6/4 light brown, hamur: 7.5 YR 6/4 light brown.

19. Ada Höyük: Çömlek parçası, el yapımı, açkı1ı, iyi pişmiş, kireç, mika katkılı, yüzey: 2.5 YR 4/4 reddish brown, hamur: $10 \mathrm{R}$ 5/8 red.

\section{Levha 3}

20. Ada Höyük: Çömlek parçası, el yapımı, açkılı, iyi pişmiş, bitki, taşcık, mika katkılı, yüzey: 7.5 R 5/4 weak red, hamur: 7.5 R 4/6 red.

21. Ada Höyük: Çömlek parçası, el yapımı, açk1l1, iyi pişmiş, bitki, iri taşcık, mika katkılı, yüzey: 10 YR 5/2 grayish brown, hamur: 2.5 YR 4/4 reddish brown.

22. Ada Höyük: Çömlek parçası, el yapımı, açkılı, iyi pişmiş, mika katkılı, yüzey: 5 R 2.5/6 dark red (mor astarl1), hamur: 5 R 2.5/1 reddish black. Gövdede dikey bant boya bezeme var. Boya bezeme krem rengindedir.

23. Ada Höyük: Çömlek parçası, el yapımı, açkı11, iyi pişmiş, mika, kireç katkıl1, yüzey: 10 R 5/8 red, hamur: Gley $15 /$ gray.

24. Ada Höyük: Çömlek parçası, el yapımı, silik açkı1l, iyi pişmiş, taşcık, kireç katkı1l, yüzey: 7.5 YR 5/2 browm, hamur: Gley 1 4/ dark gray. Gövde üzerinde konsantrik daire bezeme var.

25. Ada Höyük: Çömlek parçası, el yapımı, açkı11, iyi pişmiş, kireç, mika katkılı, yüzey: 2.5 YR 4/3 reddish brown, hamur: $7.5 \mathrm{R}$ 5/4 weak red. 
26. Ada Höyük: Çömlek parçası, el yapımı, iyi pişmiş, açkıl1, iyi pişmiş, kireç katkıl1, yüzey: 10 R 5/6 red, hamur: 2.5 YR 5/4 reddish brown.

27. Ada Höyük: Çömlek parçası, el yapımı, silik açkıl1, iyi pişmiş, taşcık, kireç katkılı, yüzey: 7.5 R 4/4 weak red, hamur: $10 \mathrm{R}$ 4/2 weak red.

28. Ada Höyük: Çömlek parçası, el yapımı, açk1lı, iyi pişmiş, kireç, mika katkılı, yüzey: 5 YR 6/4 light reddish brown, hamur: 10 YR 3/1 very dark gray.

29. Ada Höyük: Çömlek parçası, el yapımı, açkıl1, iyi pişmiş, mika katkıl1, yüzey: 7.5 YR 7/4 pink, hamur: Gley 1 4/ dark gray. Dış yüzeyde bant boya bezeme var. (Krem astar üzerine kırmızı boya bezemeli). Boya bezeme: 10 R 5/6 red.

30. Ada Höyük: Çömlek parçası, el yapımı, açkıl1, iyi pişmiş, kireç katkılı, yüzey: 7.5 YR 6/3 light brown, hamur: 7.5 YR 5/3 brown.

31. Ada Höyük: Çömlek parçası, el yapımı, açkı11, iyi pişmiş, kireç katkı11, yüzey: 5 YR 6/4 light reddish brown, hamur: 7.5 YR 5/3 brown.

32. Ada Höyük: Çömlek parçası, el yapımı, açkıl1, iyi pişmiş, ince taşcık katkılı, yüzey: 10 YR 7/3 very pale brown, hamur: 7.5 YR 5/4 brown.

33. Ada Höyük: Çömlek parçası, el yapımı, açkılı, iyi pişmiş, taşcık, kireç, mika katkıll, yüzey: 2.5 YR 4/4 reddish brown, hamur: 5 YR 4/1 dark gray.

\section{Levha 4}

34. Ada Höyük: Dikey kulp parçası, el yapımı, açkı11, iyi pişmiş, taşcık, mika katkılı, yüzey: 5 YR 6/4 light reddish brown, hamur: 7.5 YR 4/4 brown.

35. Ada Höyük: Dikey kulp parçası, el yapımı, açkısız, iyi pişmiş, bitki, taşcık, mika, kireç katkıl1, yüzey: 10 R 5/6 red, hamur: Gley 1 2.5/ black.

36. Ada Höyük: Sepet kulp parçası, el yapımı, açkı1lı, iyi pişmiş, taşcık, kireç katkı11, yüzey: 7.5 YR 5/3 brown, hamur: 5 YR 4/3 reddish brown.

37. Ada Höyük: Sepet kulp parçası, el yapımı, silik açkı11, iyi pişmiş, bitki, taşcck katkılı, yüzey: 2.5 YR 4/4 reddish brown, hamur: 10 R 6/6 light red.

38. Ada Höyük: İp delikli tutamak, el yapımı, açkı11, iyi pişmiş, taşcık, mika, kireç katkılı, yüzey: 5 YR 5/3 reddish brown, hamur: $10 \mathrm{R}$ 4/8 red.

39. Ada Höyük: Yuvarlak gövde parçası, el yapımı, açkısız, iyi pişmiş, taşcık, kireç katkı11, yüzey: 5 YR 6/4 light reddish brown, hamur: 2.5 YR 4/4 reddish brown.

40. Ada Höyük: Delikli gövde parçası, el yapımı, açkı11, iyi pişmiş, mika katkılı, yüzey: 5 YR 5/4 reddish brown, hamur: 10 R 5/8 red. Gövdede delik var. 
41. Ada Höyük: Kabartmalı gövde parçası, el yapımı, açkıl1, iyi pişmiş, taşcık katkı1l, yüzey: 2.5 YR 6/4 light reddish brown, hamur: 10 R 6/8 light red. Üç adet yuvarlak kabartma bezeme var.

42. Ada Höyük: Boya bezemeli gövde parçası, el yapımı, açkılı, iyi pişmiş, kireç katkılı, yüzey: 5 YR 7/3 pink, hamur: 7.5 YR 5/3 brown. (Krem astar üzeri kırmızı boya bezemeli), boya bezeme: 7.5 R 4/8 red.

43. Mercimeklik: Boya bezemeli gövde parçası, el yapımı, açk1lı, iyi pişmiş, taşcık, kireç katkılı, yüzey: 7.5 YR 8/2 pinkish white, boya bezeme: $7.5 \mathrm{R}$ 3/6 dark red, hamur: 7.5 YR 6/3 light brown, iç yüzey astarsı,, (krem astar üzeri kırmızı boya bezemeli).

44. Mercimeklik: Boya bezemeli gövde parçası, el yapımı, açk1lı, iyi pişmiş, kireç katkılı, yüzey: 2.5 YR 8/1 white, boya bezeme: 5 R 4/6 red, hamur: 2.5 YR 6/3 light reddish brown, iç yüzey astarsız (beyaz astar üzeri kırmızı boya bezemeli).

45. Ada Höyük: Düz dip parçası, el yapımı, açkılı, iyi pişmiş, taşcık, kireç katkılı, yüzey: 7.5 YR 3/4 dark browm, hamur: 7.5 YR 4/3 brown.

46. Ada Höyük: Düz dip parçası, el yapımı, açkı11, iyi pişmiş, taşcık katkılı, yüzey: 7.5 YR 5/3 browm, hamur: 2.5 YR 5/6 red.

47. Ada Höyük: Düz dip parçası, el yapımı, açkı1ı, iyi pişmiş, kireç, mika ve az bitki katkı1ı, yüzey: 2.5 YR 4/4 reddish brown, hamur: Gley 13 / very dark gray.

48. Ada Höyük: Düz dip parçası, el yapımı, açkıl1, iyi pişmiş, taşcık katkılı, yüzey: 2.5 YR 5/4 reddish brown, hamur $10 \mathrm{R} 4 / 8$ red.

49. Ada Höyük: Düz dip parçası, el yapımı, açkılı, iyi pişmiş, kireç katkıl1, yüzey: 10 R 5/6 red, hamur: $10 \mathrm{R}$ 6/6 light red. 


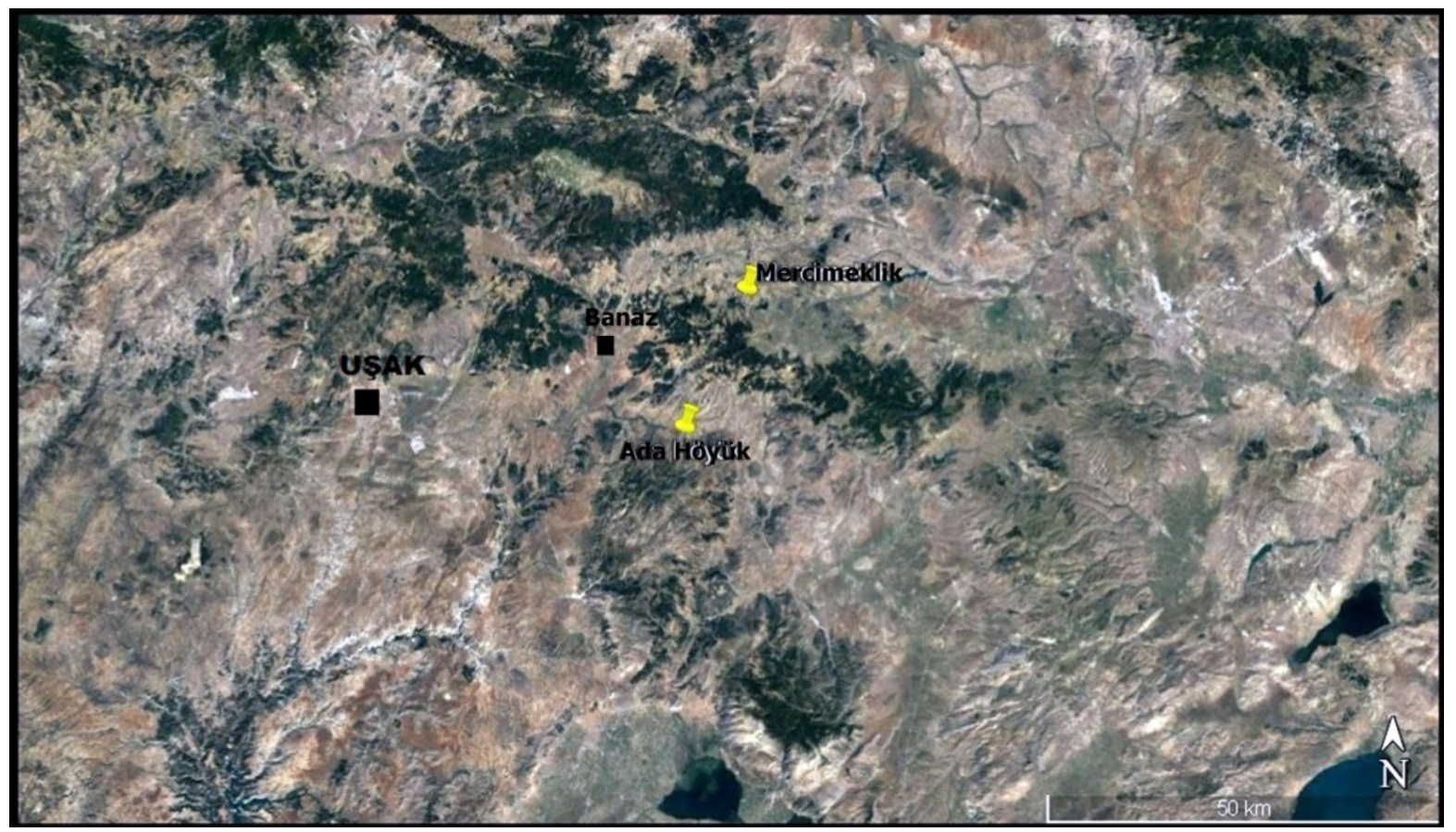

Harita 1.

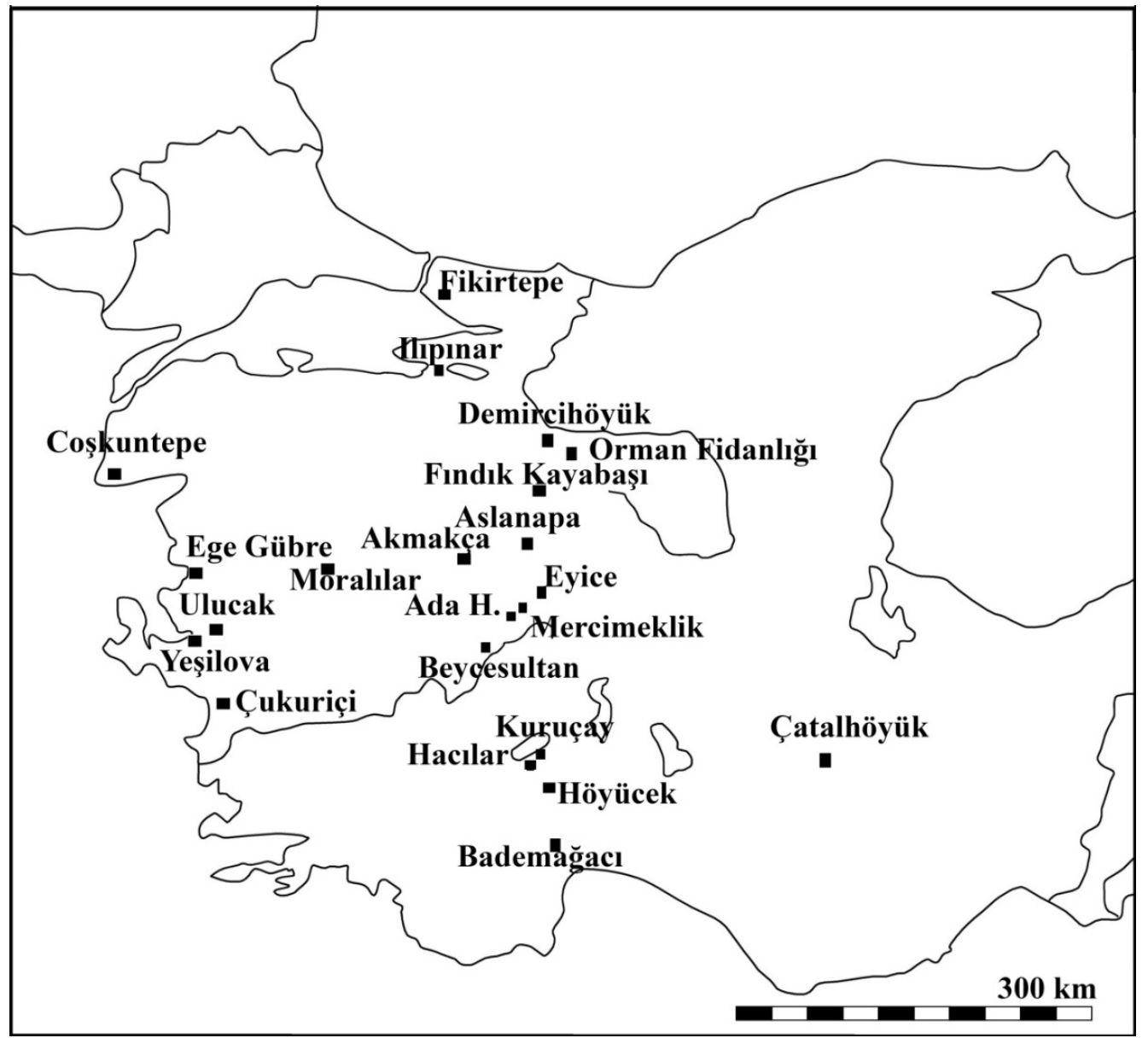

Harita 2. 


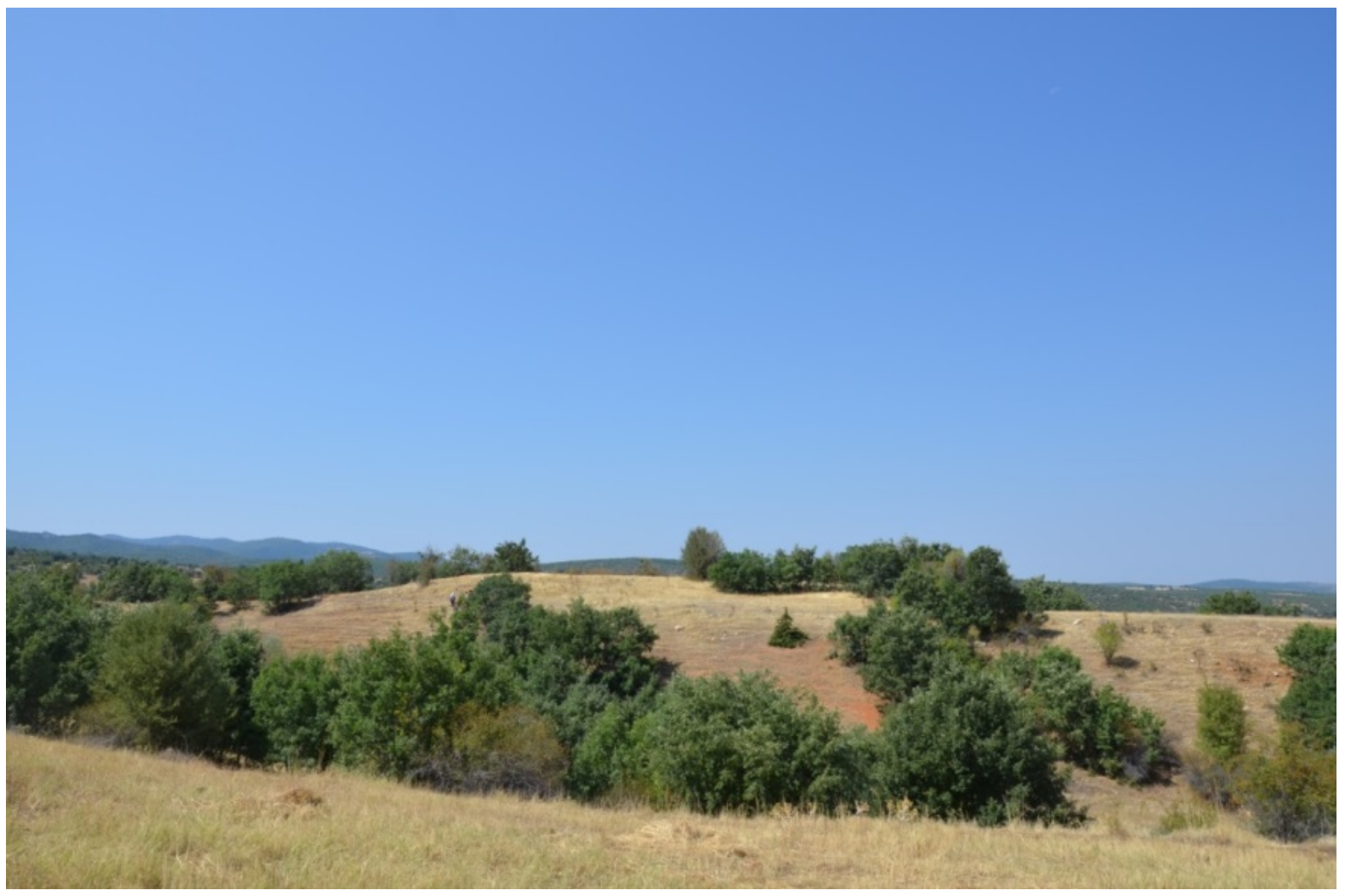

Resim 1. Ada Höyük

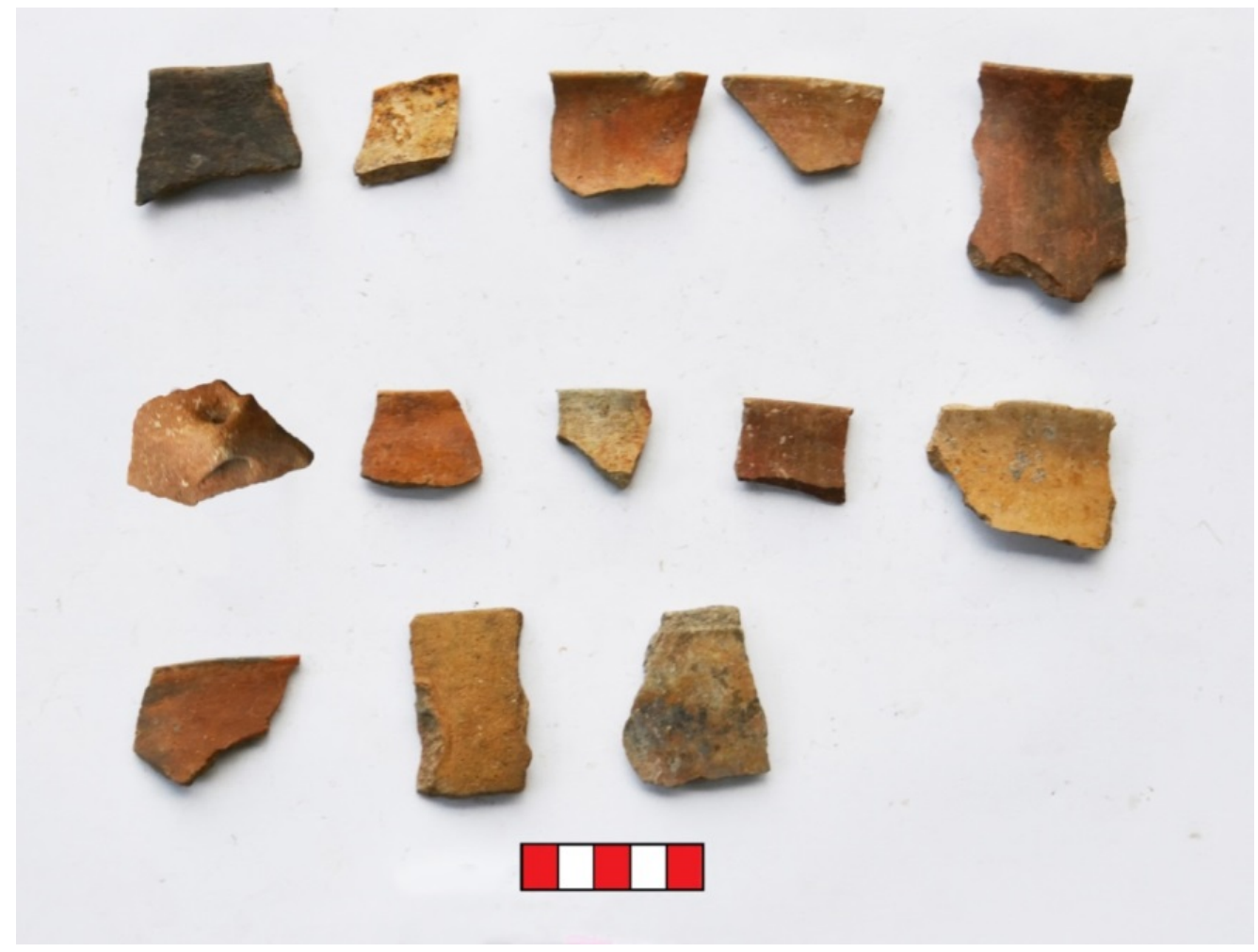

Resim 2. Ada Höyük Neolitik Çağ çanak çömleği 

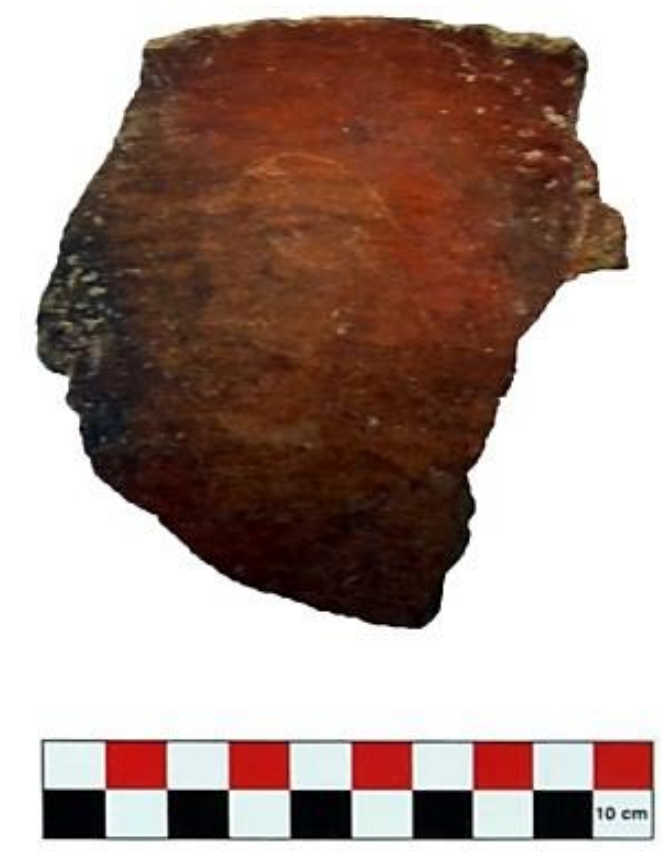

Resim 3. Neolitik Çağ kase

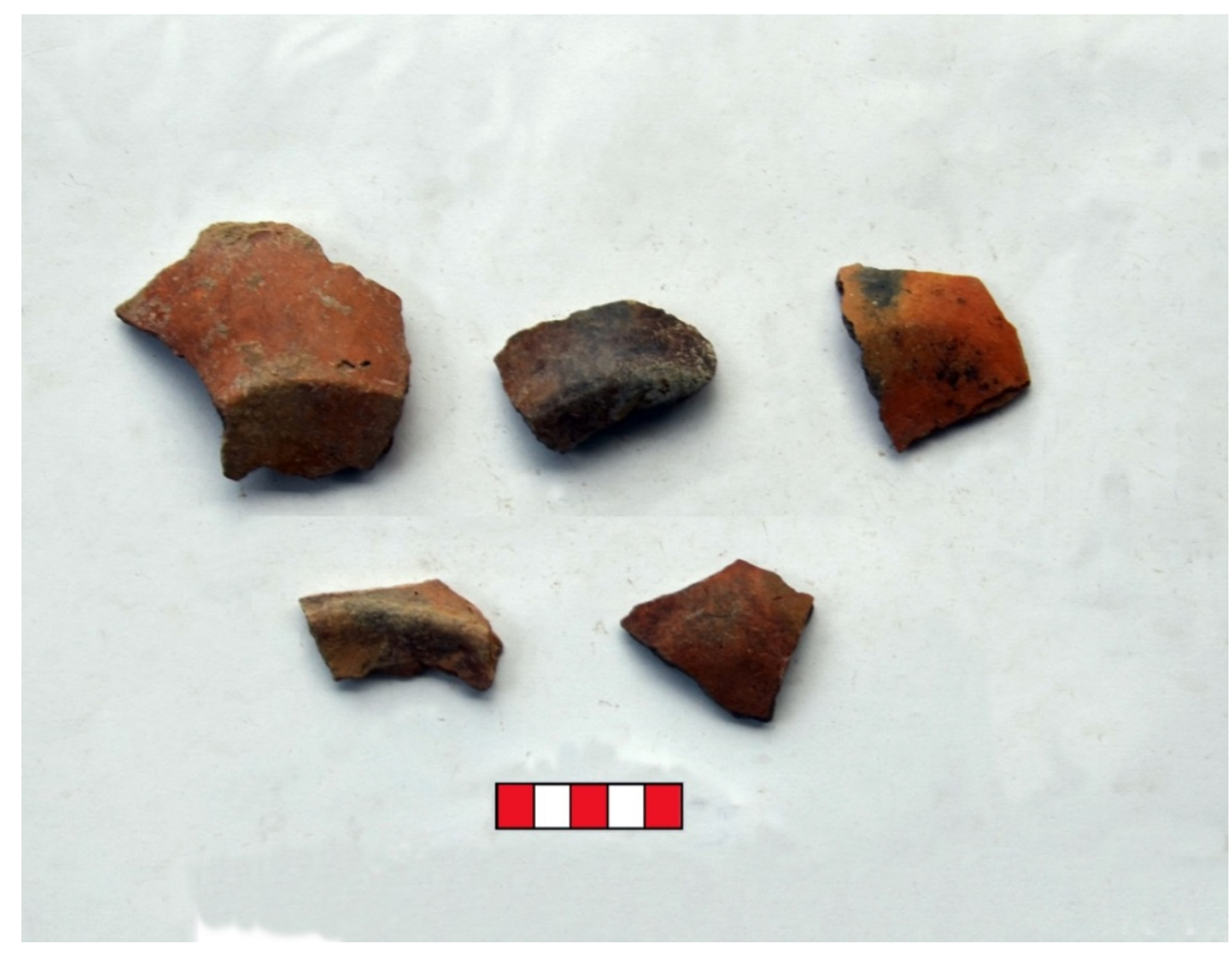

Resim 4. Neolitik Çağ dipleri 


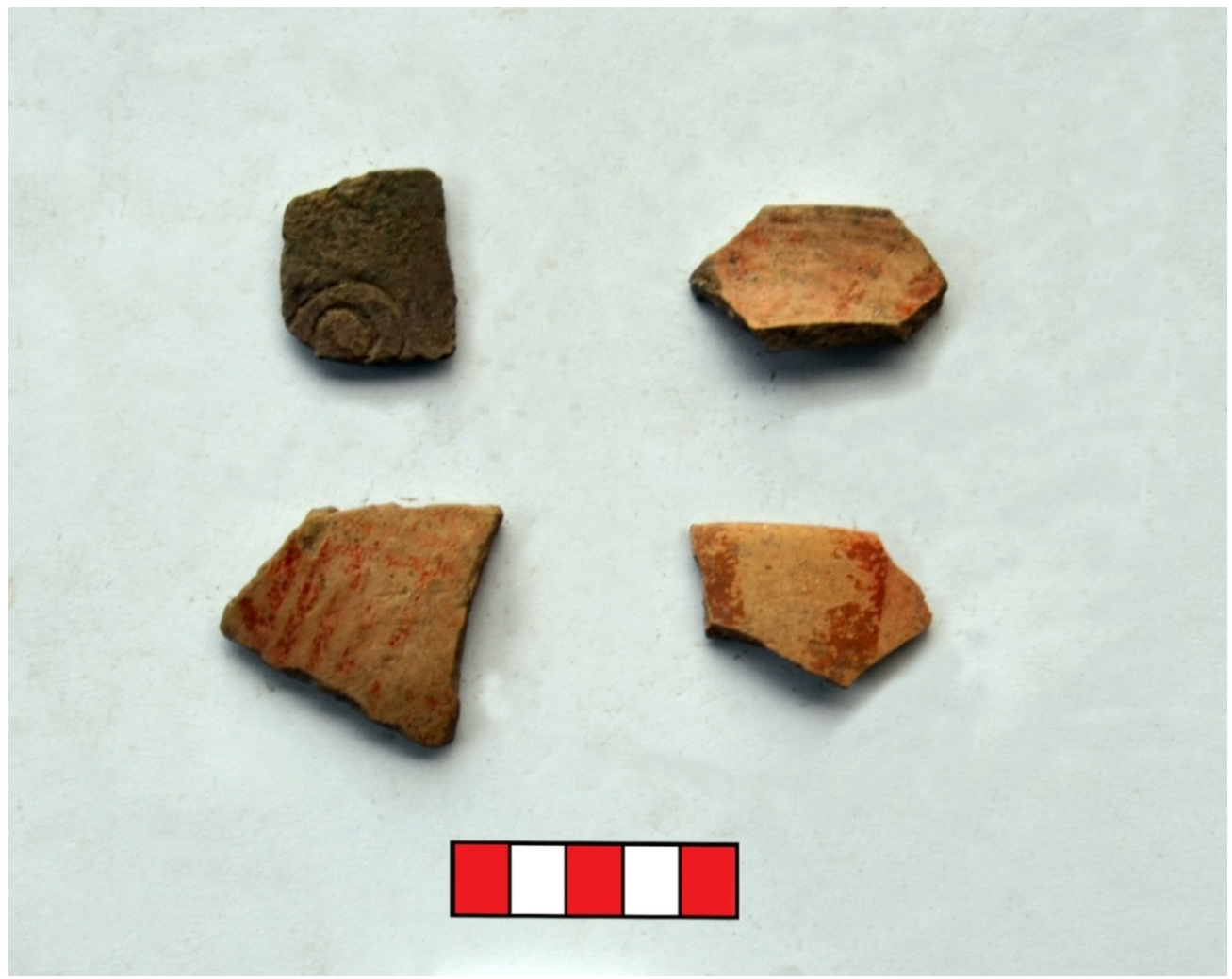

Resim 5. Bezemeli çanak çömlek

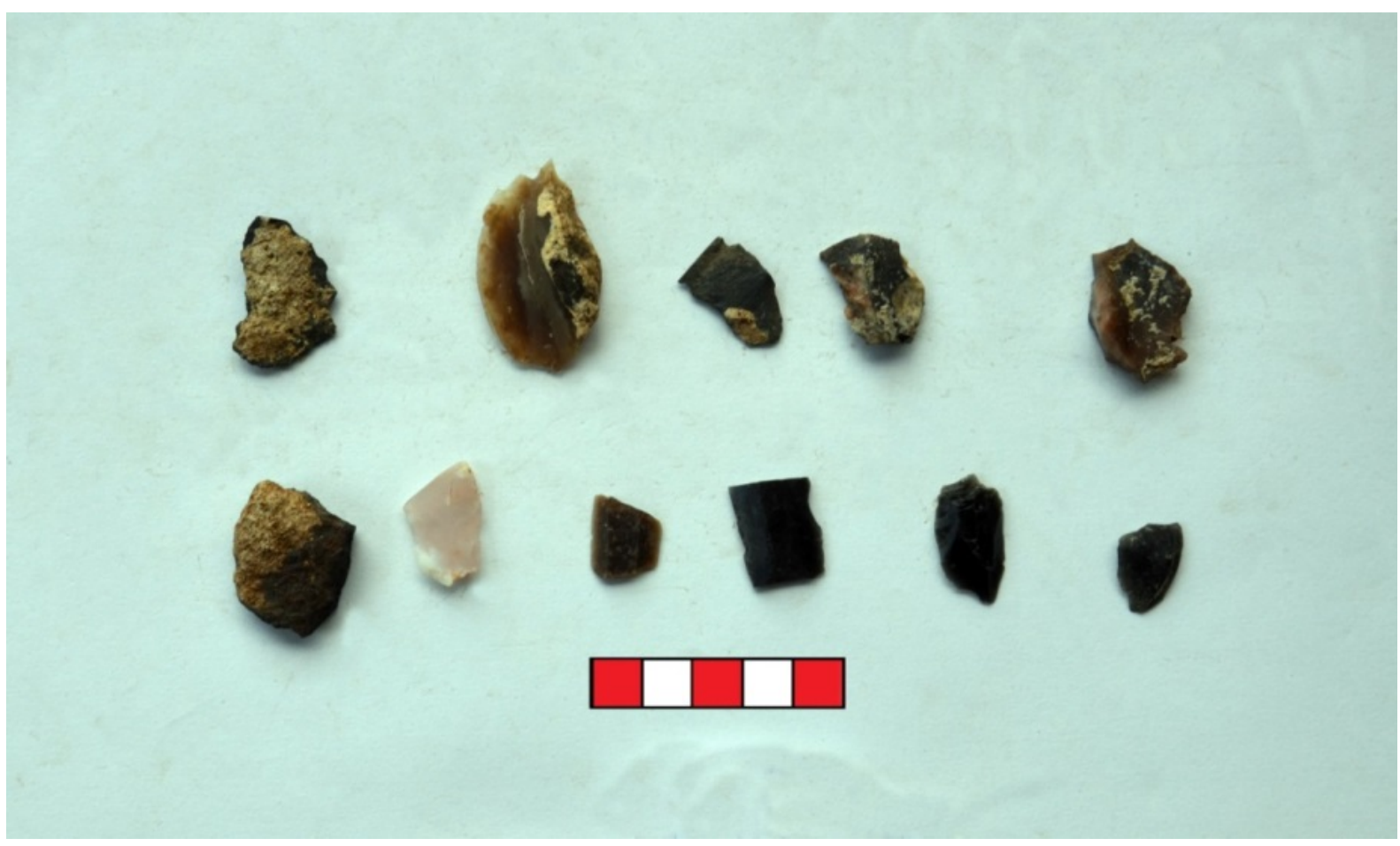

Resim 6. Çakmaktaşı ve obsidyen aletler 


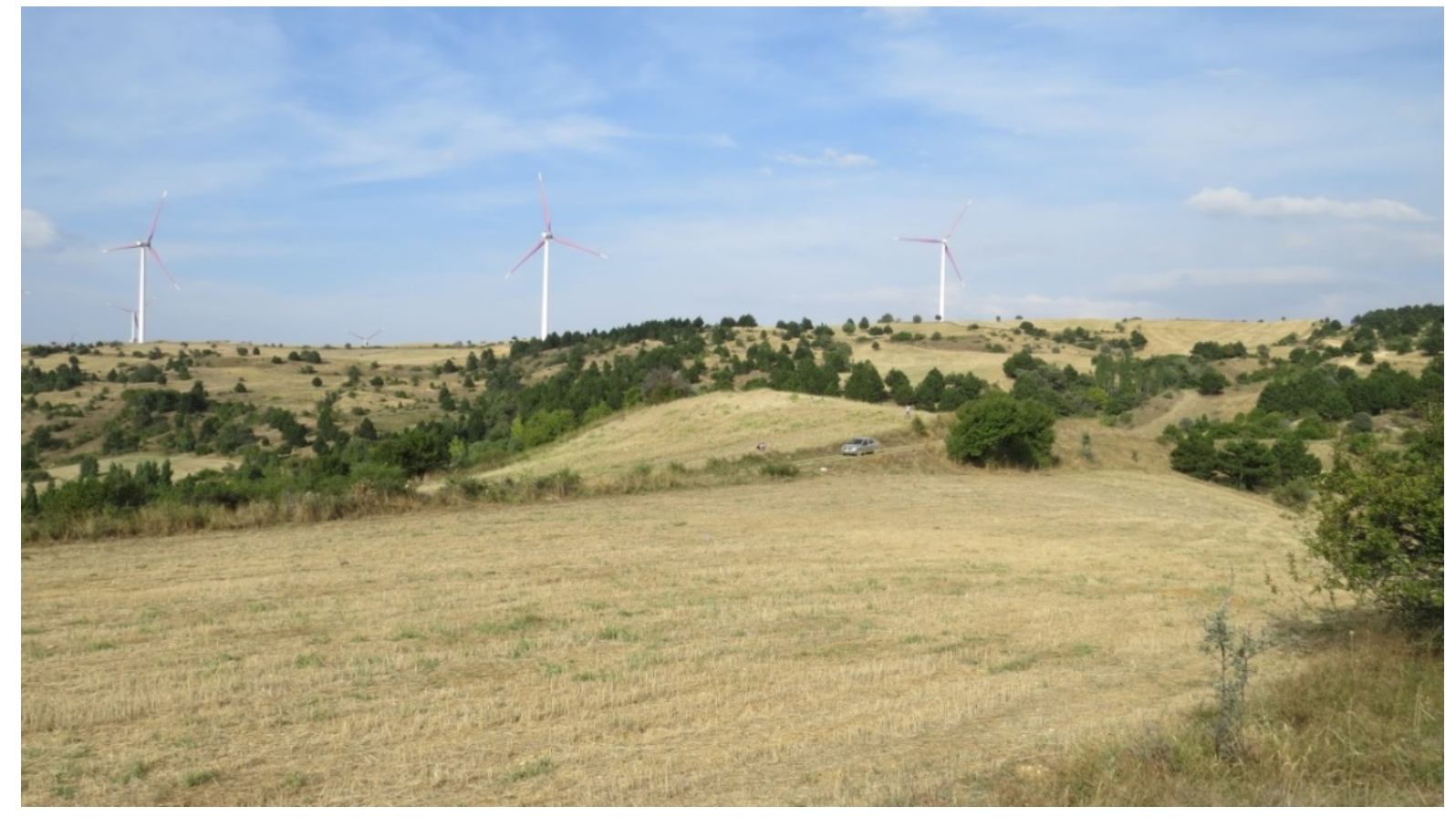

Resim 7. Mercimeklik Yerleşimi
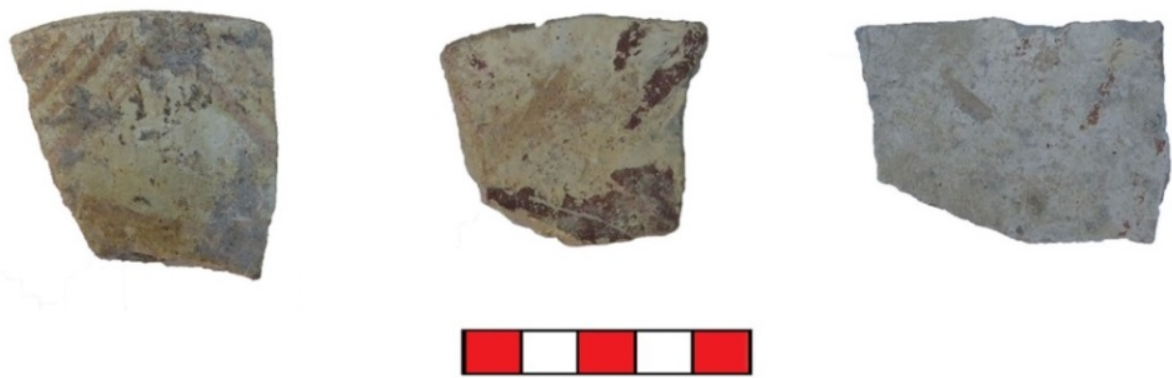

Resim 8. Mercimeklik Kalkolitik Çağ boya bezemeli çanak çömleği 


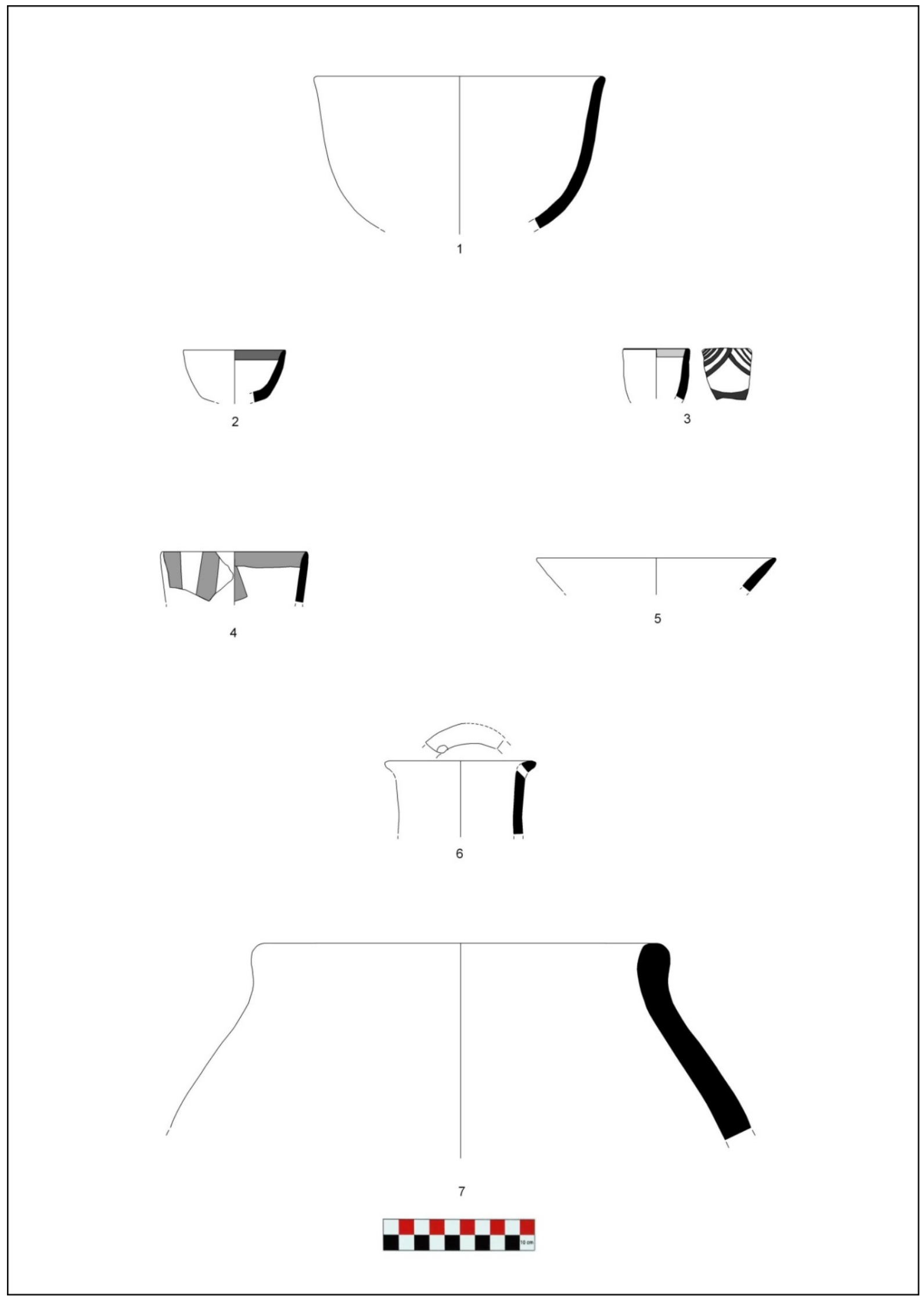

Levha 1 


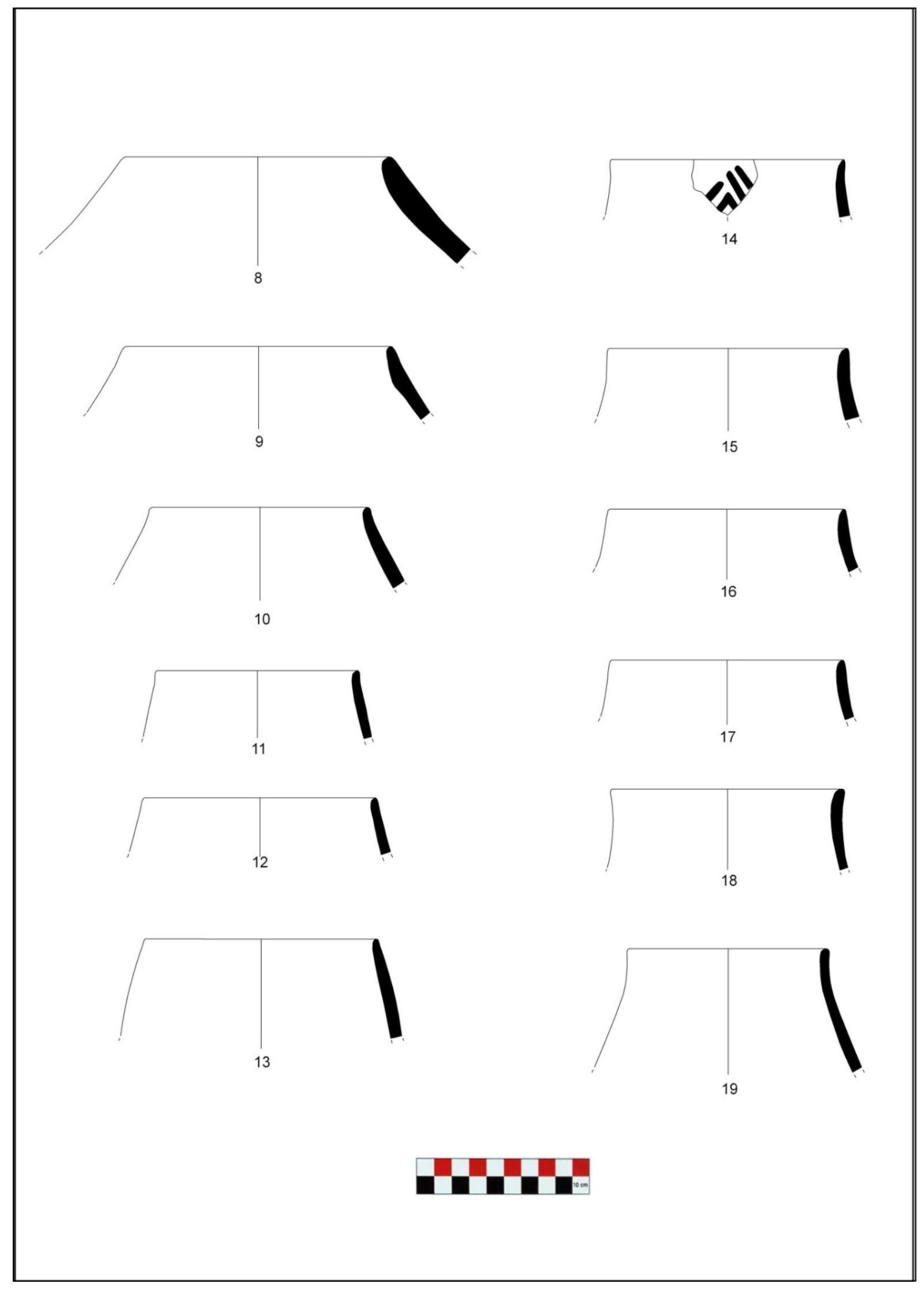

Levha 2 


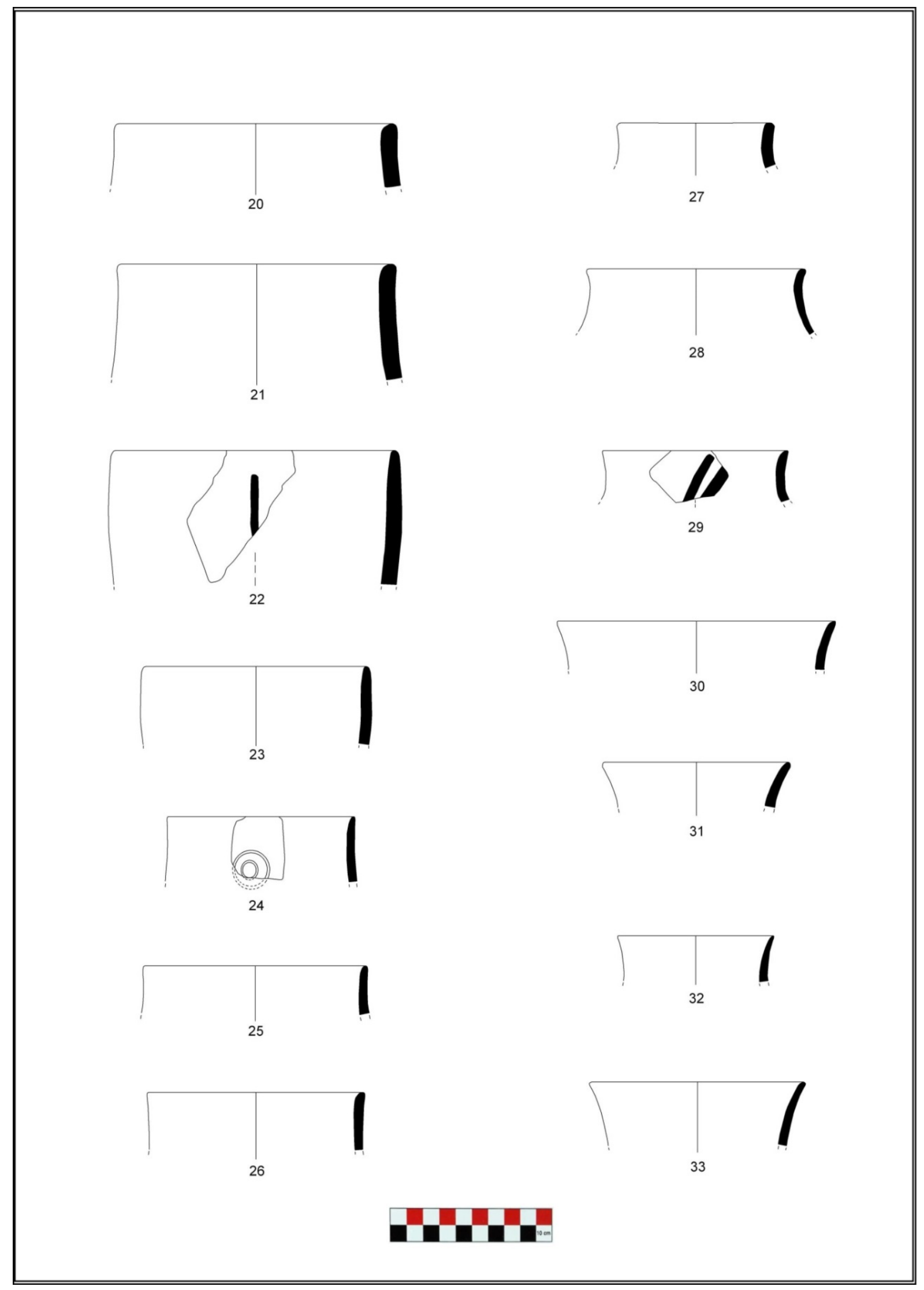

Levha 3 


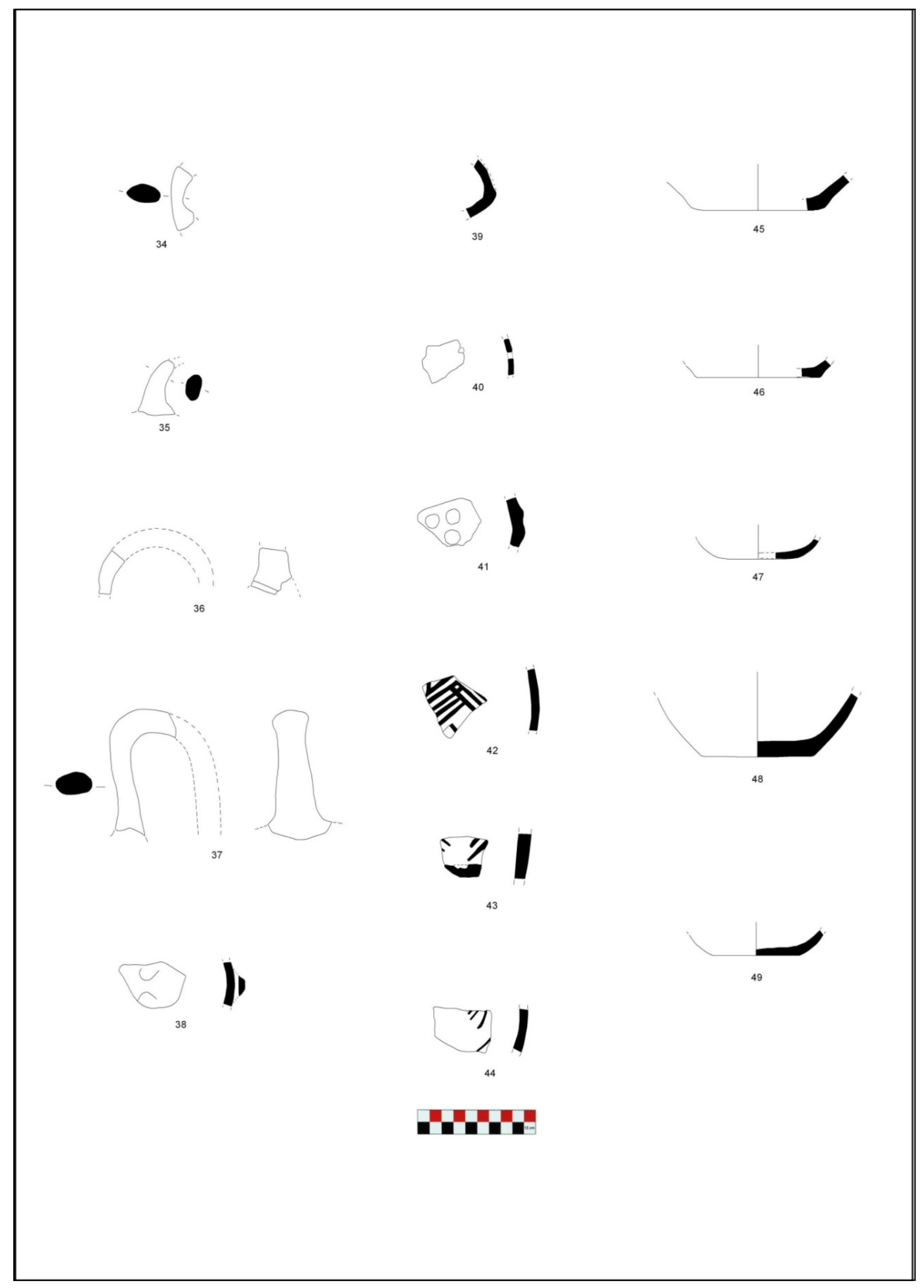

Levha 4 